\title{
THE
}

2014

\section{Mercury bioaccumulation in cartilaginous fishes from Southern New England coastal waters: Contamination from a trophic ecology and human health perspective}

\author{
David L. Taylor \\ Nicholas J. Kutil \\ Anna J. Malek \\ University of Rhode Island \\ Jeremy S. Collie \\ University of Rhode Island, jcollie@uri.edu
}

Follow this and additional works at: https://digitalcommons.uri.edu/gsofacpubs

This is a pre-publication author manuscript of the final, published article.

Creative Commons License

c) (ㅇ) $\ominus$

This work is licensed under a Creative Commons Attribution-Noncommercial-No Derivative Works 4.0 License.

\section{Citation/Publisher Attribution}

Taylor, D. L., Kutil, N. J., Malek, A. J., \& Collie, J. S. (2014). Mercury bioaccumulation in cartilaginous fishes from Southern New England coastal waters: Contamination from a trophic ecology and human health perspective. Marine Environmental Research, 99, 20-33. doi: 10.1016/j.marenvres.2014.05.009 Available at: https://doi.org/10.1016/j.marenvres.2014.05.009

This Article is brought to you for free and open access by the Graduate School of Oceanography at DigitalCommons@URI. It has been accepted for inclusion in Graduate School of Oceanography Faculty Publications by an authorized administrator of DigitalCommons@URI. For more information, please contact digitalcommons-group@uri.edu. 


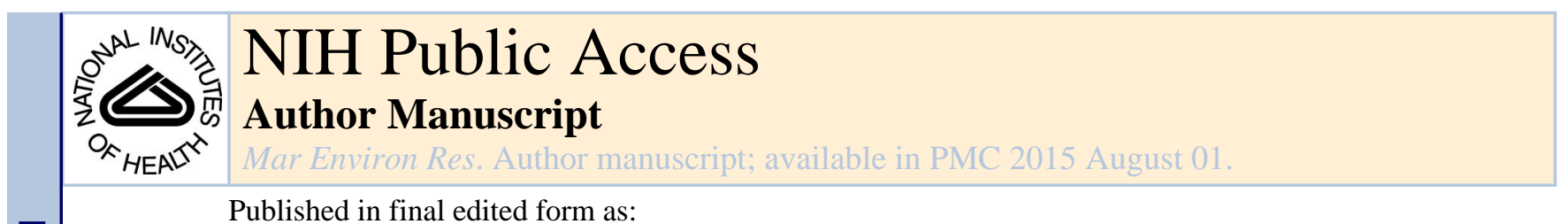

Published in final edited form as:

Mar Environ Res. 2014 August ; 99: 20-33. doi:10.1016/j.marenvres.2014.05.009.

\title{
Mercury bioaccumulation in cartilaginous fishes from Southern New England coastal waters: Contamination from a trophic ecology and human health perspective
}

\author{
David L. Taylor ${ }^{1,}$, Nicholas J. Kutil ${ }^{1}$, Anna J. Malek ${ }^{2}$, and Jeremy S. Collie ${ }^{2}$ \\ ${ }^{1}$ Roger Williams University, Department of Marine Biology, One Old Ferry Road, Bristol, RI \\ 02809, USA \\ ${ }^{2}$ University of Rhode Island, Graduate School of Oceanography, South Ferry Road, Narragansett, \\ $\mathrm{RI}, 02882$, USA
}

\section{Abstract}

This study examined total mercury $(\mathrm{Hg})$ concentrations in cartilaginous fishes from Southern New England coastal waters, including smooth dogfish (Mustelus canis), spiny dogfish (Squalus acanthias), little skate (Leucoraja erinacea), and winter skate (L. ocellata). Total $\mathrm{Hg}$ in dogfish and skates were positively related to their respective body size and age, indicating $\mathrm{Hg}$ bioaccumulation in muscle tissue. There were also significant inter-species differences in $\mathrm{Hg}$ levels (mean $\pm 1 \mathrm{SD}, \mathrm{mg} \mathrm{Hg} / \mathrm{kg}$ dry weight, $\mathrm{ppm}$ ): smooth dogfish (3.3 $\pm 2.1 \mathrm{ppm} ; n=54)>$ spiny dogfish $(1.1 \pm 0.7 \mathrm{ppm} ; n=124)>$ little skate $(0.4 \pm 0.3 \mathrm{ppm} ; n=173) \sim$ winter skate $(0.3 \pm 0.2$ ppm; $n=148)$. The increased $\mathrm{Hg}$ content of smooth dogfish was attributed to its upper trophic level status, determined by stable nitrogen $\left(\delta^{15} \mathrm{~N}\right)$ isotope analysis (mean $\delta^{15} \mathrm{~N}=13.2 \pm 0.7 \%$ ) , and the consumption of high $\mathrm{Hg}$ prey, most notably cancer crabs $(0.10 \mathrm{ppm})$. Spiny dogfish had depleted $\delta^{15} \mathrm{~N}$ signatures $(11.6 \pm 0.8 \%$ ) , yet demonstrated a moderate level of contamination by foraging on pelagic prey with a range of $\mathrm{Hg}$ concentrations, e.g., in order of dietary importance, butterfish $(\mathrm{Hg}=0.06 \mathrm{ppm})$, longfin squid $(0.17 \mathrm{ppm})$, and scup $(0.11 \mathrm{ppm})$. Skates were low trophic level consumers $\left(\delta^{15} \mathrm{~N}=11.9-12.0 \%\right.$ ) and fed mainly on amphipods, small decapods, and polychaetes with low $\mathrm{Hg}$ concentrations (0.05-0.09 ppm). Intra-specific $\mathrm{Hg}$ concentrations were directly related to $\delta^{15} \mathrm{~N}$ and carbon $\left(\delta^{13} \mathrm{C}\right)$ isotope signatures, suggesting that $\mathrm{Hg}$ biomagnifies across successive trophic levels and foraging in the benthic trophic pathway increases $\mathrm{Hg}$ exposure. From a human health perspective, $87 \%$ of smooth dogfish, $32 \%$ of spiny dogfish, and < $2 \%$ of skates had $\mathrm{Hg}$ concentrations exceeding the US Environmental Protection Agency threshold level ( $0.3 \mathrm{ppm}$ wet weight). These results indicate that frequent consumption of smooth dogfish and spiny dogfish may adversely affect human health, whereas skates present minimal risk.

(C) 2014 Elsevier Ltd. All rights reserved.

*corresponding author: Telephone: (401) 254-3759 Fax: (401) 254-3310 dtaylor@ rwu.edu.

Publisher's Disclaimer: This is a PDF file of an unedited manuscript that has been accepted for publication. As a service to our customers we are providing this early version of the manuscript. The manuscript will undergo copyediting, typesetting, and review of the resulting proof before it is published in its final citable form. Please note that during the production process errors may be discovered which could affect the content, and all legal disclaimers that apply to the journal pertain. 


\section{Keywords}

bioaccumulation; diet; dogfish; food web; mercury; skate; stable isotope

\section{Introduction}

Mercury $(\mathrm{Hg})$ is a pervasive toxicant that is introduced into the environment mainly through anthropogenic activities (US EPA, 1997). In the northeastern US, for example, Hg levels are elevated in marine coastal environments due to local point sources and distant non-point sources of contamination. The latter is dominated by the long-range transport of emissions from fossil-fuel combustion, after which the $\mathrm{Hg}$ by-product enters a water body through direct atmospheric deposition and watershed transport (Clarkson, 1992). Estuarine and coastal sediments are repositories for $\mathrm{Hg}$ (Balcom et al., 2004), and are the principal location for methylation, a bacterial-mediated process that converts inorganic $\mathrm{Hg}$ to its more toxic organic form, methylmercury (MeHg) (Gilmour et al., 1992; Benoit et al., 2003). MeHg derived from surface sediments may then be mobilized to the water column and transferred to biota through several physical and biological processes (Chen et al., 2008), including the bio-concentration of the contaminant in phytoplankton. This functional group, in turn, effectively transfers MeHg to both pelagic and benthic food webs (Mason et al., 1996; Moye et al., 2002), after which MeHg biomagnifies across successive trophic levels, concentrating in the tissues of top-level predators, including fish and other consumers (Wiener et al., 2003).

Fish are exposed to MeHg mainly through diet (Hall et al., 1997), and MeHg exposure causes numerous health deficits in fish. The severity of these adverse effects depends on the interplay between intra-species life history traits and the concentration and duration of $\mathrm{MeHg}$ exposure. Fish MeHg concentrations, for example, are positively related to body size and age when dietary intake exceeds depuration rates of the contaminant (Trudel and Rasmussen, 1997). Prey preferences and foraging ecology also impact MeHg dynamics, such that toxicant concentrations are elevated in fish feeding at higher trophic levels (Piraino and Taylor, 2009; Payne and Taylor, 2010; Szczebak and Taylor, 2011). Accordingly, fish $\mathrm{MeHg}$ bioaccumulation rates need to be examined concurrently with species-specific characteristics, such as body size, age, and ontogenetic shifts in diet and habitat use. Acute $\mathrm{MeHg}$ toxicity in fish (tissue $\mathrm{MeHg}=6.0 \mathrm{mg} / \mathrm{kg}$ wet weight) may lead to neurological disease, including reduced swimming activity and loss of equilibrium, and possibly death (Armstrong, 1979; Wiener and Spry, 1996; Smith and Weis 1997). Chronic, low-dose MeHg exposure in fish may also cause more subtle end points of toxicity (tissue $\mathrm{MeHg}=0.1 \mathrm{mg} / \mathrm{kg}$ wet weight), with possible deleterious effects to both the individual (e.g., compromised metabolism, osmoregulation, oxygen exchange, reproduction, and growth) and population (e.g., reduced survival and recruitment success) (Candelmo et al., 2010).

The majority of $\mathrm{Hg}$-related research in marine ecosystems has focused on bony fishes (Division Teleostei) because of their importance as a human food resource (US EPA, 1997). Comparatively, there is a paucity of information on $\mathrm{Hg}$ burdens in cartilaginous fishes (Subclass Elasmobranchii), although a number of these species support important 
commercial and recreational fisheries. Previous investigations on this topic have almost exclusively targeted sharks and have been limited geographically to coastal Pacific regions (Endo et al., 2009), tropical and sub-tropical waters (Heuter et al., 1995; de Pinho et al., 2002; Garcia-Hernandez et al., 2007; Maz-Courrau et al., 2012), and the pelagic-oceanic realm (Estrada et al., 2003; Branco et al., 2007; Suk et al., 2009). These prior studies revealed that many sharks experience contaminant concentrations above which adverse effects are realized, and further, may constitute a potential health risk for human consumers. There remains a lack of $\mathrm{Hg}$ research on a broad range of cartilaginous fishes from coastal regions of the Northwest Atlantic (e.g., sharks and skates), despite the ecological importance of these species in near-shore environments (Collette and Klein-MacPhee, 2002). Moreover, the broad distribution, high abundance, and upper trophic level status of cartilaginous fishes suggest that they strongly influence the fate of $\mathrm{Hg}$ in coastal habitats.

The primary objective of this study was to examine $\mathrm{Hg}$ bioaccumulation rates in cartilaginous fishes from Southern New England coastal waters, including the smooth dogfish, (Mustelus canis), spiny dogfish, (Squalus acanthias), little skate, (Leucoraja erinacea), and winter skate, (L. ocellata). Total Hg concentrations were measured in these target species and results were analyzed relative to intra-specific life history traits, including body size, age, sex, habitat use, and feeding habits. For the latter, conventional stomach content analysis was coupled with stable isotope (nitrogen and carbon) measurements to assess the effect of diet history and trophic processes on Hg contamination (Shiffman et al., 2012). Representative prey of each target fish were also analyzed for $\mathrm{Hg}$ content to determine their effect on $\mathrm{Hg}$ exposure. Lastly, given the potential value of each target species as a human dietary resource (NEFSC, 1999; 2006; NMFS, 2010), Hg results were evaluated relative to the US Environmental Protection Agency (US EPA) and US Food and Drug Administration (US FDA) criteria for the safe consumption of fishery products.

\section{Methods}

\subsection{Target fishes}

Smooth dogfish (Family Triakidae) and spiny dogfish (Family Squalidae) are the most numerically dominant shark species in the coastal western Atlantic (Collette and KleinMacPhee, 2002). Smooth dogfish are a demersal species that occupy shallow near-shore waters ( $<18 \mathrm{~m}$ to $200 \mathrm{~m}$ ) from the Bay of Fundy to Florida, with maximal abundances in the Mid-Atlantic region (Cape Hatteras, North Carolina to New Jersey). Similarly, spiny dogfish are principally located from Nova Scotia southward to Cape Hatteras, but this species occupies a broader range of continental shelf waters (shallows to $900 \mathrm{~m}$ ) and utilizes both epibenthic and pelagic habitats (Stehlik, 2007). Both smooth and spiny dogfish undergo pronounced latitudinal migrations in response to seasonal temperature changes, as well as onshore-offshore movements that are governed by prey availability and the onset of reproductive events, e.g., inshore pupping (Collette and Klein-MacPhee, 2002). Smooth and spiny dogfish also have varying life history strategies. Smooth dogfish are moderately sized [maximum size $\sim 150 \mathrm{~cm}$ total length (TL)] and have relatively fast growth rates $(15-20 \mathrm{~cm}$ TL/year) and short life spans (10-15 years). Conversely, spiny dogfish are characterized by a smaller maximum body size ( 100 and $125 \mathrm{~cm}$ TL for males and females, respectively), 
slower growth rate (1.5-3.5 cm TL/year), and extended longevity (35-40 to perhaps 100 years) (Collette and Klein-MacPhee, 2002; Stehlik, 2007). Finally, smooth dogfish are mainly benthic foragers with decapod crustaceans (crabs) representing the dominant prey, whereas the use of pelagic waters by spiny dogfish is reflected in their diet, such that fish, squid, and ctenophores are the most important food resources (Smith and Link, 2010).

Little skates and winter skates are sympatric species (Family Rajidae) with contrasting life history characteristics. Little skates are relatively small-bodied [maximum size $\sim 30 \mathrm{~cm}$ disk width (DW)] and short-lived ( 12 years), whereas winter skates have a longer life span ( 20 years) and achieve an appreciable larger body size (maximum size $\sim 60 \mathrm{~cm} \mathrm{DW}$ ) (Packer, 2003a, 2003b). The diet of both skates consist primarily of macro-invertebrates (e.g., amphipods, polychaetes, and decapod crustaceans), with fish becoming an increasingly important prey item for larger individuals (Smith and Link, 2010). Little skates and, to a lesser extent, winter skates often numerically dominant the demersal fish community in the Northwest Atlantic (Collette and Klein-MacPhee, 2002). Their specific geographic ranges are comparable and encompass coastal waters from southeastern Newfoundland to Cape Hatteras.

\subsection{Sample collection and preparation}

Dogfish, skates, and their prey were collected from Rhode Island/Block Island Sound and Narragansett Bay from May to October (2009-2012) using bottom trawls and hook \& line (Fig. 1), and specimens were identified by their time (year and day of collection) and location (latitude-longitude) of capture. Prey were selected for analysis based on their recognized dietary contribution to dogfish and skates (Smith and Link, 2010), and included scup (Stenotomus chrysops), butterfish (Peprilus triacanthus), longfin inshore squid (Doryteuthis pealeii), and cancer crabs (Cancer irroratus and C. borealis). Dogfish, skates, and prey collected in the field were either processed immediately after capture or put on ice for transportation and frozen at $-20^{\circ} \mathrm{C}$ in the laboratory for subsequent analysis.

The processing of dogfish, skates, and prey in the field and laboratory included assessing the sex of each shark and skate (presence/absence of claspers), measuring individual body size, excising muscle tissue samples, and extracting stomachs (trawl-collected dogfish and skates only). Size was measured as whole-body wet weight (g) and length or width (mm): dogfish, scup, and butterfish $=\mathrm{TL}$; skate $=\mathrm{DW}$; squid $=$ mantle length (ML); and crab $=$ carapace width $(\mathrm{CW})$. The age (years) of each dogfish and skate was also estimated from sex-specific age-length relationships reported in the literature (Soldat, 1982; Collette and KleinMacPhee, 2002; Conrath et al., 2002; Sulikowski et al., 2003; Cicia et al., 2009). Muscle tissue samples (2-5 g wet weight with skin removed) were excised from the dorsal axial musculature of dogfish and scup, pectoral wings of skates, and mantle dorsal body wall of squid using stainless-steel surgical blades, whereas crabs were processed as whole bodies. All muscle-tissue and whole-body samples were freeze-dried for $48 \mathrm{~h}$ (Labconco FreeZone 4.5-L Benchtop Freeze-Dry System), homogenized with clean stainless-steel spatulas, and stored at room temperature in borosilicate vials. The stomachs of dogfish and skates $(\sim 5$ individuals/size class/species/trawl tow; assumed to have contents) were extracted 
immediately after capture and preserved in Normalin ${ }^{\circledR}$ following the procedures of Smith and Link (2010).

\subsection{Mercury analysis}

Total $\mathrm{Hg}$ concentrations in $\mathrm{mg} / \mathrm{kg}$ dry weight (ppm) was measured in homogenized muscletissue and whole-body samples of dogfish, skates, and prey ( $0.03 \mathrm{~g}$ dry weight) using automated combustion atomic absorption spectrometry (AC-AAS) (DMA-80 Direct $\mathrm{Hg}$ Analyzer, Milestone, Inc., Shelton, Connecticut, USA), with a detection limit of $0.01 \mathrm{ng} \mathrm{Hg}$ (US EPA, 1998). The Hg analyzer was calibrated using certified reference materials (CRMs) of known Hg concentrations, and included solid standards (TORT-1: lobster hepatopancreas; DORM-2: dogfish muscle) and aqueous standards prepared by the National Research Council Canada, Institute of Environmental Chemistry (Ottawa, Canada) and the National Institute of Standards and Technology (Gaithersburg, Maryland, USA), respectively. Calibration curves were highly linear (mean $R^{2}=1.00$; range $R^{2}=0.99-1.00 ; p<0.0001$ ), and the recovery of independently analyzed samples of TORT-1, DORM-2, and PACS-2 (marine sediment) CRMs ranged from $91.9 \%$ to $107.5 \%$ (mean $=96.2 \%$ ). All samples were analyzed as duplicates, and an acceptance criterion of $10 \%$ was implemented. Duplicate samples with $<10 \%$ error were averaged for subsequent analysis (mean absolute difference between duplicates $=3.8 \%$ ). Samples with $>10 \%$ error were reanalyzed to achieve the acceptance criterion or were eliminated from further analysis. For additional quality control, blanks were analyzed every 10 samples to assess instrument accuracy and potential drift. Further, two previous studies determined that AC-AAS used in this study produced statistically equivalent results to isotope dilution gas chromatography-inductively coupled plasma mass spectrometry, with $R^{2}$ values ranging from 0.902 and 0.946 between the two methods (Piraino and Taylor, 2009; Payne and Taylor, 2010).

\subsection{Diet and trophic ecology analysis}

The contents of preserved dogfish and skate stomachs were extracted in the laboratory and the total weight of these contents was measured with analytical balances (mg wet weight). All recovered prey items were identified to the lowest practical taxon with the aid of stereomicroscopes, and when possible, the length or width of individual prey was measured as defined above. The contribution of each prey taxon to the overall diet of dogfish and skates was expressed as the frequency of occurrence $(\% F)$ and percent weight $(\% W)$. Frequency of occurrence was calculated as the number of stomachs containing a specific prey taxon divided by the total number of stomachs with prey contents, whereas percent weight was calculated as the weight of a specific prey taxon divided by the total weight of all prey types. The relative importance of each prey taxon to the diet of dogfish and skates was also assessed using a modified alimentary index (\%IA):

$$
\% I A=\frac{I A_{i}}{\sum_{i=1}^{n} I A_{i}} \times 100
$$

where, $I A$ is calculated for each prey taxon $i$ as the product of $\% F_{i}$ and $\% W_{i}$, and $n$ is the total number of prey taxa identified in the stomach contents of dogfish and skates. 
Stable isotope analysis was used to complement stomach content data and assess the effect of trophic processes on dogfish and skate $\mathrm{Hg}$ concentrations (Shiffman et al., 2012). Specifically, stable nitrogen $\left({ }^{15} \mathrm{~N} /{ }^{14} \mathrm{~N}\right)$ isotope signatures were used to estimate timeintegrated feeding history (Michener and Kaufman, 2007), whereas carbon $\left({ }^{13} \mathrm{C} /{ }^{12} \mathrm{C}\right.$ ) isotopes were used as indicators of the initial carbon source to the marine food web, thus allowing for the differentiation between pelagic and benthic trophic pathways (Fry, 2006). A sub-sample of dogfish and skates previously selected for stomach content analysis were used for stable isotope measurements (smooth dogfish: $n=41$; spiny dogfish: $n=107$; little skate: $n=90$; winter skate: $n=82$ ). Isotope measurements of a sub-sample of muscle tissue ( $1 \mathrm{mg}$ dry weight) were performed by the Boston University Stable Isotope Laboratory (Boston, Massachusetts) using automated continuous-flow isotope ratio mass spectrometry (CF-IRMS). Previous studies on the stable isotope signatures of cartilaginous fishes indicated that their muscle tissue has isotopic turnover rates of 11-14 months (MacNeil et al., 2006; Logan and Lutcavage, 2010), and in this study, muscle samples were not pretreated for lipid extraction owing to the relatively low lipid content of this tissue (Hussey et al., 2010; Kim et al., 2011). Ratios of ${ }^{15} \mathrm{~N} /{ }^{14} \mathrm{~N}$ and ${ }^{13} \mathrm{C} /{ }^{12} \mathrm{C}$ are described using the standard delta notation $(\delta)$, expressed as the relative per mil $(\% o)$ difference between the samples and international standards (atmospheric nitrogen, ${ }^{15} \mathrm{~N}_{\text {air }}$, and Vienna Pee Dee Belemnite, ${ }^{13} \mathrm{C}_{\mathrm{V}-\mathrm{PDB}}$, respectively), and calculated using the following equation:

$$
\delta X=\left(R_{\text {sample }} / R_{\text {standard }}-1\right) \times 1000 \quad(\%)
$$

where, $X$ is ${ }^{15} \mathrm{~N}$ or ${ }^{13} \mathrm{C}$ and $R$ is ${ }^{15} \mathrm{~N} /{ }^{14} \mathrm{~N}$ or ${ }^{13} \mathrm{C} /{ }^{12} \mathrm{C}$. The recovery of internal reference materials (peptone and glycine) for the CF-IRMS method was $99.6 \%$ and $99.7 \%$ for nitrogen and carbon, respectively. The mean sample precision determined from duplicate analyses was $98.6 \%$ (range $=90.2-100.0 \%)$ and $99.5 \%($ range $=93.1-100.0 \%)$ for nitrogen and carbon, respectively.

\subsection{Data analysis}

Inter-species differences in mean total $\mathrm{Hg}$ concentrations and isotopic signatures $\left(\delta^{15} \mathrm{~N}\right.$ and $\delta^{13} \mathrm{C}$ ) among dogfish and skates were analyzed with two-way analysis of variance (ANOVA) models using species and sex as fixed factors, whereas differences in prey $\mathrm{Hg}$ content across taxa were examined with a one-way ANOVA model. The post hoc separation of mean differences in $\mathrm{Hg}$ and isotope values across 4 levels of target species and 4 levels of prey species (Hg only) were contrasted with independent Ryan-Einot-Gabriel-Welsch (Ryan's Q) multiple comparison tests. Prior to these analyses, data were $\log _{10}$-transformed to meet assumptions of normality and homogeneity of variance. The effects of body size, age, and isotopic values on the $\mathrm{Hg}$ concentration of dogfish, skates, and prey (size only) were analyzed with least-squares exponential regressions (size and age) and linear regressions $\left(\delta^{15} \mathrm{~N}\right.$ and $\delta^{13} \mathrm{C}$ ). Also for dogfish and skates, analysis of covariance (ANCOVA) models were used to assess the effect of sex and species on $\mathrm{Hg}$ bioaccumulation rates, with age as the covariate and sex or species as the discrete explanatory variable. Lastly, multiple linear regression analysis was used to assess the effects of several biotic and abiotic variables on $\mathrm{Hg}$ concentrations and isotopic signatures of dogfish and skates. Five regression models were employed that either examined: (1) the independent effects of body size, location of 
catch (latitude and longitude; decimal degrees), and time of catch (year and day of collection) on the response variables, or (2) the cumulative effects of all predictor variables, as determined from global and stepwise linear regression models. Small-sample, biascorrected Akaike's Information Criterion $\left(\mathrm{AIC}_{\mathrm{c}}\right)$ and Akaike's weights $\left(w_{i}\right)$ were used to evaluate and select the optimal regression model (Burnham and Anderson, 2002):

$$
\begin{gathered}
A I C_{\mathrm{c}}=-2 \log [\mathscr{L}(\hat{\theta})]+2 K+\frac{2 K(K+1)}{n-K-1} \\
w_{i}=\exp \left(-0.5 \Delta_{i}\right) / \sum_{k=1}^{5} \exp \left(-0.5 \Delta_{k}\right)
\end{gathered}
$$

where, $\mathscr{L}$ is the likelihood function of the model parameters, $n$ is the sample size, $K$ is the number of regression parameters, and $\Delta_{i}$ is equal to $\mathrm{AIC}_{\mathrm{c}, i}-\mathrm{AIC}_{\mathrm{c}, \min }$. The model with the smallest $\mathrm{AIC}_{\mathrm{c}}$ value $\left(\mathrm{AIC}_{\mathrm{c}, \mathrm{min}}\right)$ had the most support, and the $w_{i}$ value quantified the probability that model $i$ was the best among the candidate models.

\section{Results and Discussion}

\subsection{Mercury concentrations and bioaccumulation in cartilaginous fishes}

Mean total $\mathrm{Hg}$ concentrations varied significantly among dogfish and skate species, but not as a function of their sex (Tables 1 and 2). Smooth dogfish had the highest mean $\mathrm{Hg}$ concentration (mean $\pm 1 \mathrm{SD}=3.3 \pm 2.1 \mathrm{ppm})$, followed by spiny dogfish $(1.1 \pm 0.7 \mathrm{ppm})$ and skates (little: $0.4 \pm 0.3 \mathrm{ppm}$; winter: $0.3 \pm 0.2 \mathrm{ppm}$ ) (Fig. $2 \mathrm{~A}$ ). The $\mathrm{Hg}$ concentrations reported in this study are consistent with literature values for conspecifics and congeners from other geographic areas, including those collected from European and Asian waters (Table 3). Conversely, there is also evidence of spatial and temporal variations in target fish $\mathrm{Hg}$ content. In US coastal environments, for example, spiny dogfish collected from the Pacific during the early to mid-1970s had markedly higher $\mathrm{Hg}$ concentrations relative to Atlantic conspecifics (Table 3). In the northwestern Atlantic, the mean $\mathrm{Hg}$ content of spiny dogfish has ostensibly declined $\sim 35 \%$ over the last several decades. Winter skate $\mathrm{Hg}$ concentrations in this study were also $\sim 50 \%$ greater than levels measured in equally-sized conspecifics from New York commercial markets, where skates were collected from a relatively broad geographic area (mid- to north Atlantic; U.S. EPA, 2013). The observed spatio-temporal differences in fish $\mathrm{Hg}$ burdens are attributed to geographic variability and historical changes in contaminant inputs to coastal habitats (Benoit et al., 2003); the latter includes biota directly responding to recent reductions in point sources of $\mathrm{Hg}$ in the northeastern US (Sunderland et al., 2012). Moreover, geochemical, physicochemical, and ecological processes in marine coastal habitats vary over relatively small spatial and temporal scales, thus affecting $\mathrm{Hg}$ mobilization and its eventual incorporation and transfer through trophic pathways (Chen et al., 2008).

Total $\mathrm{Hg}$ concentrations in dogfish and skates were directly related to their body size and age (Table 4; Figs. 3 and 4), confirming the accumulation of $\mathrm{Hg}$ in muscle tissue.

Multivariate regression analysis and estimates of the $\mathrm{AIC}_{\mathrm{c}}$ and $w_{i}$ further revealed that body 
size was the most significant factor affecting the $\mathrm{Hg}$ content of all species (Table 5), although the level of influence varied between dogfish $\left(R^{2}=0.27-0.29\right)$ and skates $\left(R^{2}=\right.$ $0.08-0.10)$. There were also significant seasonal and annual variations in spiny dogfish and winter skate $\mathrm{Hg}$ concentrations (Table 5), but these factors contributed minimally to the cumulative $R^{2}$-values for each model (day and year partial $R^{2}$-values $=0.03-0.04$ ). Previous studies purported Hg bioaccumulation in dogfish (Forrester et al., 1972; Hall et al., 1977; de Pinho et al., 2002; Endo et al., 2009; 2013), which is attributed to the disproportionate uptake of $\mathrm{Hg}$ relative to its low depuration rate (Maz-Courrau et al., 2012). In contrast, Storelli et al. (1998) found no correlation between the $\mathrm{Hg}$ content of three skate species (Raja spp.) and their respective body weight.

Total $\mathrm{Hg}$ concentrations varied significantly by sex in little skates when age was included as a covariate, such that females had increased contaminant levels at a given age relative to males (Table 6). Conversely, Hg concentrations did not differ between sexes in dogfish and winter skates (Table 6). The absence of gender-specific Hg burdens in dogfish is inconsistent with prior studies, and to the knowledge of the authors, has not been examined in skates. Endo et al. (2009; 2013) observed that male spiny dogfish (16-41 years) and starspotted dogfish (Mustelus manazo) (4-8 years) had higher $\mathrm{Hg}$ concentrations relative to females (S. acanthias: 18-61 years; M. manazo: 2-14 years), which is caused by the cessation of somatic growth in mature male dogfish. In this study, the lack of gender effects on dogfish $\mathrm{Hg}$ concentrations were likely due to the comparatively narrow age ranges examined in target fishes (Table 1); noting that Endo et al. (2009; 2013) reported negligible differences in sex-specific $\mathrm{Hg}$ concentrations at younger age classes.

$\mathrm{Hg}$ bioaccumulation rates did not differ between smooth and spiny dogfish, and similarly, between little and winter skates (ANCOVA: Age $\times$ Species, $p=0.06-0.16$; Table 6). At a defined age, however, smooth dogfish and little skates had higher $\mathrm{Hg}$ concentrations than spiny dogfish and winter skates, respectively (Table 6; Fig. 4). It is well documented that rapid somatic growth in bony fishes reduces overall $\mathrm{Hg}$ burdens through growth dilution; a response caused by the disproportionate increase in fish size relative to $\mathrm{Hg}$ dietary intake (Wang, 2012 and references therein). Results from this study contradict growth dilution because of the increased $\mathrm{Hg}$ content of faster growing species (Collette and Klein-MacPhee, 2002; Frisk et al., 2006). Endo et al. (2013) also obtained results that refuted $\mathrm{Hg}$ biodilution in cartilaginous fishes, such that the star-spotted dogfish had higher $\mathrm{Hg}$ concentrations compared to slower growing spiny dogfish. Differences in the growth rates between mustelid and squalid dogfish (M. canis: 15-20 cm TL/year; S. acanthias: $1.5-3.5 \mathrm{~cm}$ TL/ year; Collette and Klein-MacPhee, 2002; Stehlik, 2007) are also reflected in their metabolic expenditures (Mustelus norrisi: $161 \mathrm{mg} \mathrm{O} / 2 \mathrm{~kg} / \mathrm{hr}$ at $26^{\circ} \mathrm{C} ;$ S. acanthias: $92 \mathrm{mg} \mathrm{O} / \mathrm{kg} / \mathrm{hr}$ at $22^{\circ} \mathrm{C}$; Brett and Blackburn, 1978; Bushnell et al., 1989; Carlson and Parsons, 2001). To sustain their comparatively high bioenergetic demands (i.e., growth and metabolism), mustelid dogfish have elevated feeding rates, expressed as \% body weight consumed per day (Mustelus californicus: 1.3-1.6\%; S. acanthias $=0.4-1.3 \%$; Holden, 1966; Jones and Green, 1977; San Filippo, 1996), thus concurrently increasing their dietary uptake and exposure to $\mathrm{Hg}$. Further, differences in the food habits and $\mathrm{Hg}$ content of preferred prey, as discussed in 
subsequent sections, likely obscure the $\mathrm{Hg}$ growth dilution response in dogfish and skates (Stafford and Haines, 2001).

\subsection{Diet and trophic ecology of cartilaginous fishes}

Direct visual analysis of smooth dogfish $(n=34)$, spiny dogfish $(n=57)$, little skate $(n=$ $125)$, and winter skate $(n=92)$ stomach contents revealed inter-species differences in feeding habits (Tables 7 and 8), and the results herein are consistent with previous diet analyses of the target fishes (Smith and Link, 2010). The mean standardized weight of stomach contents was greater in dogfish than skates (stomach content weight/whole-body wet weight $\sim 2-3 \%$ and $0.3-0.4 \%$, respectively), whereas skates generally had more distinct prey taxa in a single stomach compared to dogfish (4.2-4.5 and 2.0-3.5 unique prey/stomach, respectively). The results also suggest that spiny dogfish have a more restricted overall diet relative to smooth dogfish and skates (Tables 7 and 8); spiny dogfish consumed a total of 13 different prey taxa, whereas 18-21 novel prey taxa were identified in the stomachs of smooth dogfish and skates (excluding "unidentified" categories).

Spiny dogfish mostly consumed pelagic prey (bony fish and squid), whereas smooth dogfish fed almost exclusively on benthic invertebrates (crustaceans and polychaetes) (Table 7). The dominant prey of spiny dogfish, with respect to frequency of occurrence, were butterfish, scup, unidentified fish, longfin squid, and cancer crabs. Butterfish also accounted for the largest percentage by weight of spiny dogfish stomach contents, followed by longfin squid, unidentified fish, scup, and silver hake. The order of importance of prey to the diet of spiny dogfish, as expressed by the alimentary index (\%IA), were butterfish, longfin squid, and unidentified fish, while the remaining prey groups had \%IA less than $3 \%$. Cancer crabs, polychaetes, and unidentified animal tissue (including fish and crabs) were the most frequency encountered prey in smooth dogfish stomachs, followed by algae/detritus, and other decapod crustaceans. According to other measures of dietary importance, cancer crabs and unidentified fish were the most utilized prey resource by smooth dogfish, while all remaining prey were of lesser importance $(\% I A<1 \%)$.

Little skates and winter skates mostly consumed benthic prey (Table 8). Amphipods were the most frequently observed prey in skate stomachs, followed by polychaetes and other crustaceans, including sand shrimp, cancer crabs, and isopods. Amphipods and polychaetes also accounted for a high percentage of the stomach weight in both skate species, while fish also contributed considerably to the stomach weight of larger winter skates (> $350 \mathrm{~mm} \mathrm{DW}$ ), including sand lance and scup. The order of prey dietary importance for skates, expressed as $\% I A$, were amphipods, polychaetes, sand shrimp, and cancer crabs, while the remaining identifiable prey taxa had \%IA less than $3 \%$.

Stable nitrogen $\left(\delta^{15} \mathrm{~N}\right)$ isotope signatures were used to approximate the trophic status of dogfish and skates (Michener and Kaufman, 2007), and mean $\delta^{15} \mathrm{~N}$ values varied significantly among target fish (Table 2). Smooth dogfish had a significantly enriched $\delta^{15} \mathrm{~N}$ signature relative to spiny dogfish $(13.2 \pm 0.7$ and $11.6 \pm 0.8 \%$, respectively), which corresponds to smooth dogfish occupying a higher trophic position (Fig. 2B). The depleted $\delta^{15} \mathrm{~N}$ signature of spiny dogfish is attributed to the dietary contribution of low trophic level prey, including planktivorous forage fish (e.g., butterfish; \%IA = 48.4\%; Table 7) and 
possibly ctenophores (Smith and Link, 2010), although ctenophores were not detected in dogfish stomachs due to their fragile tissues. Moreover, female spiny dogfish $(11.7 \pm 0.7 \%$ o $)$ had a significantly higher $\delta^{15} \mathrm{~N}$ value relative to male conspecifics $(10.8 \pm 0.4 \%$ ), thus explaining the species-sex interaction effect in the twoway ANOVA model (Table 2). Little and winter skates had significantly lower $\delta^{15} \mathrm{~N}$ signatures than smooth dogfish, but the mean $\delta^{15} \mathrm{~N}$ values between skate species did not differ (little: $12.0 \pm 0.7 \%$; winter: $11.9 \pm 1.0 \%$; Fig. 2B), suggesting that these species occupy the same, relatively low, trophic level.

Stable carbon $\left(\delta^{13} \mathrm{C}\right)$ isotope signatures were used to differentiate among varying sources of primary production to the coastal food web, and thus, distinguish between benthic and pelagic trophic linkages (Peterson and Howarth, 1987; France, 1995). Mean $\delta^{13} \mathrm{C}$ values ranged from -22.0 to $-16.5 \%$ and varied significantly among dogfish and skates, but not as a function of their sex (Table 2; Fig. 2C). Moreover, two distinct isotopic groups were evident that further corroborated this study's stomach content analysis. The depleted $\delta^{13} \mathrm{C}$ value of spiny dogfish ( -22\%o) indicated a phytoplankton-based (pelagic) food web, which is consistent with their preferred consumption of butterfish and squid. Conversely, the more enriched $\delta^{13} \mathrm{C}$ signatures $(\sim-17 \%$ ) of smooth dogfish and skates suggest benthic sources of primary production, which is presumably derived from their consumption of epibenthic crustaceans and infaunal polychaetes.

Body size, location of catch (latitude and longitude), and time of catch (day of year and year) were the most significant factors affecting dogfish and skate isotopic signatures (Table 5). The estimated slope coefficients for the size- $\delta^{15} \mathrm{~N}$ relationship were positive for spiny dogfish and skates, indicating that older individuals forage at higher trophic levels. There was also an inverse relationship between body size and $\delta^{13} \mathrm{C}$ values in winter skates, which is attributed to larger skates (> $350 \mathrm{~mm} \mathrm{DW}$ ) consuming pelagic prey, including butterfish, sand lance, and squid (Table 8). Dogfish and skate isotopic signatures also exhibited significant spatio-temporal variations (Table 5). Specifically, $\delta^{15} \mathrm{~N}$ and $\delta^{13} \mathrm{C}$ values increased in a northeasterly direction, in closer proximity to the mainland ("+" and "-_" coefficient for latitude and longitude, respectively) (Fig. 1), as well as becoming more enriched as the sampling season progressed ("+" coefficient for day of year and year). It is unlikely that differences in dogfish and skate foraging ecology accounted for the observed spatio-temporal variations in isotopic values. It is more probable that these differences are the result of species-specific seasonal and annual migrations, and thus, spatio-temporal variability in habitat use. This is especially relevant to dogfish because of their expansive coastal migrations (Collette and Klein-MacPhee, 2002). Moreover, the added effect of sitespecific environmental conditions (e.g., spatially-explicit salinity profiles, terrestriallyderived and increased nutrient loading along the immediate coastline) can have pronounced effects on the isotopic signatures of the target fishes (Pruell et al., 2006; Michener and Kaufman, 2007).

\subsection{Trophic effects on cartilaginous fish mercury concentrations}

Representative prey of dogfish and skates were measured for total $\mathrm{Hg}$ content to assess their potential effect on target fish $\mathrm{Hg}$ levels (Table 1). Mean prey $\mathrm{Hg}$ concentrations varied significantly across taxa (Table 2; Fig. 2D), such that scup had the highest Hg content (0.29 
$\pm 0.18 \mathrm{ppm})$, followed by crabs $(0.16 \pm 0.11 \mathrm{ppm})$, squid $(0.11 \pm 0.04 \mathrm{ppm})$, and butterfish $(0.07 \pm 0.4 \mathrm{ppm})$. Prey $\mathrm{Hg}$ concentrations were also positively related to body size (Table 4; Fig. 5), again indicating the bioaccumulation of the contaminant. Inter-species differences in dogfish and skate $\mathrm{Hg}$ concentrations are adequately explained by the $\mathrm{Hg}$ content of their preferred prey. In this study, smooth dogfish had the highest $\mathrm{Hg}$ concentration among target fishes, and this species preferentially consumed cancer crabs with a mean body size of 55 $\mathrm{mm} \mathrm{CW}$, i.e., the mean size of crabs recovered from smooth dogfish stomachs (Table 7). Crabs of this relatively large size have an estimated $\mathrm{Hg}$ content of $0.10 \mathrm{ppm}$, as determined from the $\mathrm{Hg}$-size regression model (Table 4). It is important to reiterate that crabs in this study were processed as whole bodies, whereas the $\mathrm{Hg}$ content of other prey was measured in excised muscle tissue. This discrepancy in tissue-type likely underestimates the $\mathrm{Hg}$ concentration of cancer crabs. For example, the $\mathrm{Hg}$ content of blue crab (Callinectes sapidus) muscle tissue is $\sim 30 \%$ greater than the $\mathrm{Hg}$ burden of whole-body samples (Adams and Engel, 2014). Spiny dogfish had a moderate level of $\mathrm{Hg}$ contamination, and this species relied on prey that had both low and high $\mathrm{Hg}$ concentrations; in order of dietary importance, butterfish ( $\mathrm{Hg}=0.06 \mathrm{ppm}$ for $108 \mathrm{~mm}$ TL fish), longfin squid $(\mathrm{Hg}=0.17 \mathrm{ppm}$ for $168 \mathrm{~mm}$ ML squid), and scup ( $\mathrm{Hg}=0.11 \mathrm{ppm}$ for $94 \mathrm{~mm}$ TL fish) (Tables 4 and 7). Finally, little and winter skates had the lowest $\mathrm{Hg}$ concentrations observed in this study, and these species fed upon amphipods, polychaetes, and small cancer crabs $(<20 \mathrm{~mm} \mathrm{CW})$. Payne and Taylor (2010) measured the $\mathrm{Hg}$ content of amphipods and polychaetes collected from the Narragansett Bay estuary (Fig. 1), each with a mean Hg concentration of 0.09 ppm (converted from wet weight). It is important to note that such prey species would likely have reduced $\mathrm{Hg}$ burdens in Rhode Island/Block Island Sound, as the environment is further removed from anthropogenic influences (Taylor et al., 2012). Moreover, the estimated $\mathrm{Hg}$ content of cancer crabs consumed by skates was $0.05 \mathrm{ppm}(8-18 \mathrm{~mm} \mathrm{CW}$ ) (Tables 4 and 8). These collective results indicate that dogfish and skates are highly responsive to the $\mathrm{Hg}$ content of their preferred prey.

Stable isotope ( $\left({ }^{15} \mathrm{~N}\right.$ and $\delta^{13} \mathrm{C}$ ) analysis was coupled with total $\mathrm{Hg}$ data to provide insight into the effects of trophic processes on $\mathrm{Hg}$ contamination in dogfish and skates. There were significant positive relationships between $\mathrm{Hg}$ and $\delta^{15} \mathrm{~N}$ values measured for spiny dogfish and skates (Table 4; Fig. 3); hence verifying an increase in intra-specific $\mathrm{Hg}$ concentrations at higher trophic levels. These results are consistent with previous analyses of the trophic effects on marine fish $\mathrm{Hg}$ concentrations, including several species of coastal and oceanic sharks (Adams et al., 2003; Cai et al., 2007; Suk et al., 2009; Maz-Courrau et al., 2012). Significant positive relationships were also observed between $\mathrm{Hg}$ and $\delta^{13} \mathrm{C}$ values measured for dogfish and little skates (Table 4; Fig. 3). This result suggests that benthic associations may increase biotic $\mathrm{Hg}$ concentrations via dietary intake or proximate contact with $\mathrm{Hg}$ contaminated sediments, as reported elsewhere (Storelli et al., 1998; Hosseini et al., 2013). Other studies, however, indicate that pelagic-feeding organisms (depleted $\delta^{13} \mathrm{C}$ signatures) have increased $\mathrm{Hg}$ exposure (Chen et al., 2009; Kim et al., 2012). Ultimately, the fate of $\mathrm{Hg}$ through feeding pathways depends on the number of trophic steps and consumer's utilization of different prey assemblages (Kim et al., 2012), which likely vary across discrete aquatic ecosystems. 


\subsection{Cartilaginous fish mercury contamination from a human health perspective}

The $\mathrm{Hg}$ concentrations in some fish may be sufficiently high to adversely affect human health (McMichael and Butler, 2005; Willett, 2005), and human exposure to $\mathrm{Hg}$ occurs mainly through dietary intake of contaminated fish (Hightower and Moore, 2003). Public health officials affiliated with federal and state agencies respond to the threat of fish $\mathrm{Hg}$ contamination by reporting criteria for the safe consumption of fishery products, including the US FDA and US EPA threshold levels of 1.0 and $0.3 \mathrm{ppm} \mathrm{Hg}$ wet weight, respectively. Cartilaginous fishes are becoming increasingly utilized as a human food source given the precipitous declines in traditional fisheries (NEFSC, 1999; 2006; NMFS, 2010), thus underscoring the importance of research focused on $\mathrm{Hg}$ contamination in these species. For the purposes of comparing the results of this study to the US FDA and US EPA action levels, $\mathrm{Hg}$ data originally expressed as dry weight were converted to wet weight assuming $75 \%$ water content of the muscle tissue (Bosch et al., 2013). Accordingly, 24.1\% of smooth dogfish, $1.6 \%$ of spiny dogfish, and $0.0 \%$ of skates exceeded the US FDA criterion of 1.0 ppm $\mathrm{Hg}$ wet weight. For the more conservative US EPA threshold ( $0.3 \mathrm{ppm} \mathrm{Hg}$ ), $87.0 \%$ of smooth dogfish, $32.0 \%$ of spiny dogfish, and $<2 \%$ of skates were above this value. The $\mathrm{Hg}$ length exponential regression models also estimated that smooth and spiny dogfish obtain $\mathrm{Hg}$ concentrations of $0.3 \mathrm{ppm}$ at relatively small body sizes $(57.3$ and $70.9 \mathrm{~cm} \mathrm{TL}$, respectively), whereas skates do not approach this threshold level even at their maximum body sizes (39.0 and $133.9 \mathrm{~cm} \mathrm{DW}$, respectively) (Table 4).

\section{Conclusions}

In this study, total $\mathrm{Hg}$ concentrations were measured in dogfish and skates, and results were evaluated relative to species-specific life history traits. The total $\mathrm{Hg}$ content of dogfish and skate muscle tissue was positively related to body size and age, indicating the bioaccumulation of the contaminant. Moreover, $\mathrm{Hg}$ concentrations were significantly elevated in smooth dogfish, followed by spiny dogfish and skates. The increased $\mathrm{Hg}$ content of smooth dogfish was attributed to its upper trophic level status, consumption of $\mathrm{Hg}$ enriched prey (e.g., large cancer crabs), and relatively high bioenergetic requirements. Comparatively, spiny dogfish had a reduced trophic status owing to the dietary contribution of butterfish, yet demonstrated a moderate level of $\mathrm{Hg}$ contamination because this species also consumed high Hg prey (e.g., squid and scup). Little and winter skates were basal consumers and had the lowest $\mathrm{Hg}$ concentrations because they fed exclusively on $\mathrm{Hg}$ depleted prey (e.g., amphipods, small decapods, and polychaetes). The collective results from the analysis of stable isotopes further indicated that $\mathrm{Hg}$ biomagnifies across successive trophic levels and foraging in the benthic trophic pathway may increase $\mathrm{Hg}$ exposure. From a human health perspective, the consumption of smooth dogfish and, to a lesser extent, spiny dogfish pose a human health risk, and therefore, justifies stringent consumption advisories for these species. Conversely, the consumption of skates does not present a significant risk to human health. It is the recommendation of the authors that this information be effectively communicated to the general public so that citizens can make informed decisions regarding the safe consumption of fishery resources. 


\section{Acknowledgements}

We are grateful to S. Olszewski (Rhode Island Division of Fish and Wildlife, Jamestown, RI), D. Palance, A. Hall, N. Kutil, G. LeBlanc, and B. Bourque (Roger Williams University, Bristol, RI) for assistance in sample collection and preparation. We also thank the captain and crew of the F/V Darana R and staff of the Northeast Area Monitoring and Assessment Program survey for their able assistance in collecting the offshore samples. We thank R. Michener (Boston University Stable Isotope Laboratory, Boston, MA) for stable isotope analyses. The project described was supported by the Roger Williams University Foundation Fund Based Research Grant, the Rhode Island Ocean Special Area Management Plan, the Commercial Fisheries Research Foundation - Southern New England Cooperative Research Initiative, and by Award P20RR016457 from the National Center for Research Resources. The content is solely the responsibility of the authors and does not necessarily represent the official views of the National Center for Research Resources or the National Institutes of Health.

\section{References}

Adams DH, Engel ME. Mercury, lead, and cadmium in blue crabs, Callinectes sapidus, from the Atlantic coast of Florida, USA: A multipredator approach. Ecotoxicology and Environmental Safety. 2014; 102:196-201. [PubMed: 24507459]

Adams, DH.; McMichael, RH.; Henderson, GE. Technical Report, TR-9. 2nd ed.. Florida Marine Research Institute; St. Petersburg, FL: 2003. Mercury Levels in Marine and Estuarine Fishes of Florida 1989-2001..

Armstrong, FAJ. Effects of mercury compounds on fish.. In: Nriagu, JO., editor. The Biogeochemistry of Mercury in the Environment. Elsevier/North Holland Biomedical Press; New York: 1979. p. 657-670.

Asante KA, Agusa T, Mochizuki H, Ramu K, Inoue S, Kubodera T, Subramanian A, Tanabe S. Trace elements and stable isotopes $\left(\delta^{13} \mathrm{C}\right.$ and $\left.\delta^{15} \mathrm{~N}\right)$ in shallow and deep-water organisms from the East China Sea. Environmental Pollution. 2008; 156:862-873. [PubMed: 18583004]

Balcom PH, Fitzgerald WF, Vandal GM, Lamborg CH, Rolfhus KR, Langer CS, et al. Mercury sources and cycling in the Connecticut River and Long Island Sound. Marine Chemistry. 2004; 90:53-74.

Benoit, JM.; Gilmour, CC.; Heyes, A.; Mason, RP.; Miller, CL. Biogeochemistry of Environmentally Important Trace Elements. ACS Symposium Series 835. American Chemical Society; Washington, DC: 2003. Geochemical and biological controls over methylmercury production and degradation in aquatic ecosystems.; p. 262-297.

Bosch AC, Sigge GO, Kerwath SE, Cawthorn DM, Hoffman LC. The effects of gender, size and lifecycle stage on the chemical composition of smoothhound (Mustelus mustelus) meat. Journal of the Science of Food and Agriculture. 2013; 93:2384-2392. [PubMed: 23413175]

Branco V, Vale C, Canário J, Santos M. Mercury and selenium in blue shark (Prionace glauca, L. 1758) and swordfish (Xiphias gladius, L. 1758) from two areas of the Atlantic Ocean. Environmental Pollution. 2007; 150:373-380. [PubMed: 17376573]

Brett JR, Blackburn JM. Metabolic rate and energy expenditure of the spiny dogfish (Squalus acanthias). Journal of the Fisheries Research Board of Canada. 1978; 35:816-821.

Burnham, KP.; Anderson, DR. Model Selection and Multimodel Inference: A Practical InformationTheoretical Approach. 2nd ed.. Springer-Verlag, New York; New York: 2002.

Bushnell PG, Lutz PL, Gruber SH. The metabolic rate of an active, tropical elasmobranch, the lemon shark (Negaprion brevirostris). Experimental Biology. 1989; 48:279-283. [PubMed: 2620710]

Cai Y, Rooker JR, Gill GA, Turner JP. Bioaccumulation of mercury in pelagic fishes from northern Gulf of Mexico. Canadian Journal of Fisheries and Aquatic Sciences. 2007; 64:458-469.

Candelmo AC, Deshpande A, Dockum B, Weis P, Weis JS. The effect of contaminated prey on feeding, activity, and growth of young-of-the-year bluefish, Pomatomus saltatrix, in the laboratory. Estuaries and Coasts. 2010; 33:1025-1038.

Carlson JK, Parsons GR. The effects of hypoxia on three sympatric shark species: Physiological and behavioral responses. Environmental Biology of Fishes. 2001; 61:427-433. 
Chen C, Amirbahman A, Fisher N, Harding G, Lamborg C, Nacci D, Taylor D. Methylmercury in marine ecosystems: Spatial patterns and processes of production, bioaccumulation, and biomagnification. EcoHealth. 2008; 5:399-408. [PubMed: 19015919]

Chen CY, Dionne M, Mayes BM, Ward DM, Sturup S, Jackson BP. Mercury bioavailability and bioaccumulation in estuarine food webs in the Gulf of Maine. Environmental Science and Technology. 2009; 43:1804-1810. [PubMed: 19368175]

Childs EA, Gaffke JN. Mercury content of Oregon groundfish. Fishery Bulletin. 1972; 71:713-717.

Chouvelon T, Spitz J, Caurant F, Mèndez-Fernandez P, Autier J, Lassus-Débat A, Chappuis A, Bustamante P. Enhanced bioaccumulation of mercury in deep-sea fauna from the Bay of Biscay (North-East Atlantic) revealed by stable isotope analysis. Deep-Sea Research. 2012; 65:113-124.

Cicia AM, Driggers WB, Ingram GW Jr. Kneebone J, Tsang PCW, Koester DM, Sulikowski JA. Age and size at sexual maturity for little skate, Leucoraja erinacea, in the western Gulf of Maine based on estimates of three parameters. Journal of Fish Biology. 2009; 75:1648-1666. [PubMed: 20738640]

Clarkson TW. Mercury: Major issues in environmental health. Environmental Health Perspectives. 1992; 100:31-38. [PubMed: 8354179]

Collette, BB.; Klein-MacPhee, G., editors. Bigelow and Schroeder's Fishes of the Gulf of Maine. 3rd ed.. Smithsonian Inst. Press.; Washington, DC: 2002. p. 748

Conrath CL, Gelsleichter J, Musick JA. Age and growth of the smooth dogfish (Mustelus canis) in the northwest Atlantic Ocean. Fishery Bulletin. 2002; 100:674-682.

de Pinho AP, Guimarães JRD, Martins AS, Costa FPAS, Olavo G, Valentin J. Total mercury in muscle tissue of five shark species form Brazilian offshore waters: Effects of feeding habitat, sex and length. Environmental Research Section A. 2002; 89:250-258.

Dixon R, Jones B. Mercury concentrations in stomach contents and muscle of five fish species from the North East coast of England. Marine Pollution Bulletin. 1994; 28:741-745.

Endo T, Hisamichi Y, Kimura O, Kotaki Y, Kato Y, Ohto C, Koga N, Haraguchi K. Contamination levels of mercury in the muscle of female and male spiny dogfishes (Squalus acanthias) caught off the coast of Japan. Chemosphere. 2009; 77:1333-1337. [PubMed: 19863992]

Endo T, Hisamichi Y, Kimura O, Ogasawara H, Ohta C, Koga N, Kato Y, Haraguchi K. Levels of mercury in muscle and liver of star-spotted dogfish (Mustelus manazo) from the northern region of Japan: A comparison with spiny dogfish (Squalus acanthias). Archives of Environmental Contamination and Toxicology. 2013; 64:467-474. [PubMed: 23271344]

Estrada JA, Rice AN, Lutcavage ME, Skomal GB. Predicting trophic position in sharks of the northwest Atlantic Ocean using stable isotope analysis. Journal of the Marine Biological Association. 2003; 83:1347-1350.

Forrester CR, Ketchen KS, Wong CC. Mercury content of spiny dogfish (Squalus acanthias) in the Strait of Georgia, British Columbia. Journal of the Fisheries Research Board of Canada. 1972; 29:1487-1490.

France RL. Carbon-13 enrichment in benthic compared to planktonic algae: Food web implications. Marine Ecology Progress Series. 1995; 124:307-312.

Frisk MG, Miller TJ. Age, growth, and latitudinal patterns of two Rajidae species in the northwestern Atlantic: Little skate (Leucoraja erinacea) and winter skate (Leucoraja ocellata). Canadian Journal of Fisheries and Aquatic Sciences. 2006; 63:1078-1091.

Fry B, Sherr EB. $\delta^{13} \mathrm{C}$ measurements as indicators of carbon flow in marine and freshwater ecosystems. Contributions in Marine Science. 1984; 27:13-47.

Garcia-Hernandez J, Cadena-Cardenas L, Betancourt-Lozano M, Garcia-De-La-Parra LM, GarciaRico L, Marquez-Farias F. Total mercury content found in edible tissues of top predator fish from the Gulf of California, Mexico. Toxicological and Environmental Chemistry. 2007; 89:507-522.

Gerhart EH. Concentrations of total mercury in several fishes from Delaware Bay, 1975. Pesticides Monitoring Journal. 1977; 11:132-133. [PubMed: 609511]

Gilmour CG, Henry EA, Mitchell R. Sulfate stimulation of mercury methylation in freshwater sediments. Environmental Science and Technology. 1992; 26:2281-2287. 
Greig RA, Wenzloff D, Shelpuk C, Adams A. Mercury concentrations in three species of fish from North Atlantic offshore waters. Archives of Environmental Contamination and Toxicology. 1977; 5:315-323. [PubMed: 869588]

Hall AS, Teeny FM, Gauglitz EJ Jr. Mercury in fish and shellfish of the Northeast Pacific, III. Spiny dogfish, Squalus acanthias. Fishery Bulletin. 1977; 75:642-645.

Hall BD, Bodaly RA, Fudge RJ, Rudd JW, Rosenberg DM. Food as the dominant pathway of methylmercury uptake by fish. Water, Air, and Soil Pollution. 1997; 100:13-24.

Heuter RE, Fong WG, Henderson G, French MF, Manire CA. Methylmercury concentration in shark muscle by species, size, and distribution of sharks in Florida coastal waters. Water, Air, and Soil Pollution. 1995; 80:893-899.

Hightower JM, Moore D. Mercury levels in high-end consumers of fish. Environmental Health Perspectives. 2003; 111:1-6.

Holden MJ. The food of the spurdog, Squalus acanthias (L.). Journal du Conseil Permanent International pour l'Exploration de la Mer. 1966; 30:255-266.

Hosseini M, Nabavi SMB, Parsa Y. Bioaccumulation of trace mercury in trophic levels of benthic, benthopelagic, pelagic fish species, and sea birds from Arvand River, Iran. Biological Trace Element Research. 2013; 156:175-180. [PubMed: 24174062]

Hussey NE, Brush J, McCarthy ID, Fisk AT. $\delta^{15} \mathrm{~N}$ and $\delta^{13} \mathrm{C}$ diet-tissue discrimination factors for large sharks under semi-controlled conditions. Comparative Biochemistry and Physiology. Part A, Molecular \& Integrative Physiology. 2010; 155:445-453.

Jones BC, Green GH. Food and feeding of spiny dogfish (Squalus acanthias) in British Columbia waters. Journal of the Fisheries Research Board of Canada. 1977; 34:2067-2078.

Kim E, Kim H, Shin K, Kim M, Kundu SR, Lee B, Han S. Biomagnification of mercury through the benthic food webs of a temperate estuary: Masan Bay, Korea. Environmental Toxicology and Chemistry. 2012; 31:1254-1263. [PubMed: 22447737]

Kim SL, Casper DR, Galván-Magaña F, Ochoa-Díaz R, Hernández-Aguilar SB, Koch PL. Carbon and nitrogen discrimination factors for elasmobranch soft tissues based on a long-term controlled feeding study. Environmental Biology of Fishes. 2011; 95:37-52.

Kousteni V, Megalofonou P, Dassenakis M, Stathopoulou E. Total mercury concentrations in edible tissues of two elasmobranch species from Crete (eastern Mediterranean Sea). Cybium. 2006; 30:119-123.

Logan JM, Lutcavage ME. Stable isotope dynamics in elasmobranch fishes. Hydrobiologia. 2010; 644:231-244.

MacNeil MA, Drouillard KG, Fisk AT. Variable uptake and elimination of stable nitrogen isotopes between tissues in fish. Canadian Journal of Fisheries and Aquatic Sciences. 2006; 63:345-353.

Mason RP, Reinfelder JR, Morel FMM. Uptake, toxicity, and trophic transfer of mercury in a coastal diatom. Environmental Science and Technology. 1996; 30:1835-1845.

Maz-Courrau A, López-Vera C, Galván-Magaña F, Escobar-Sánchez O, Rosíles-Martínez R, SanjuánMuñoz A. Bioaccumulation and biomagnification of total mercury in four exploited shark species in the Baja California Peninsula, Mexico. Bulletin of Environmental Contamination and Toxicology. 2012; 88:129-134. [PubMed: 22187022]

McMichael AJ, Butler CD. Fish, health, and sustainability. American Journal of Preventive Medicine. 2005; 29:322-323. [PubMed: 16242597]

Michener, RH.; Kaufman, L. Stable isotope ratios as tracers in marine food webs: An update.. In: Lajtha, K.; Michener, RH., editors. Stable Isotopes in Ecology and Environmental Science. Blackwell Scientific; Boston: 2007. p. 238-278.

Moye HA, Miles CJ, Phlips EJ, Sargent B, Merritt KK. Kinetics and uptake mechanisms for monomethylmercury between freshwater algae and water. Environmental Science and Technology. 2002; 36:3550-3555. [PubMed: 12214648]

National Marine Fisheries Service (NMFS). Final Amendment 3 to the Consolidated Atlantic Highly Migratory Species Fishery Management Plan. National Oceanic and Atmospheric Administration, National Marine Fisheries Service, Office of Sustainable Fisheries, Highly Migratory Species Management Division, Silver Spring; MD: 2010. p. 632 
Northeast Fisheries Science Center (NEFSC). Assessment of the Northeast Region Skate Complex for 1999. Stock Assessment Review Committee Southern Demersal Working Group, NEFSC; Woods Hole, Massachusetts: 1999.

Northeast Fisheries Science Center (NEFSC). $43^{\text {rd }}$ Northeast Regional Stock Assessment Workshop (43 ${ }^{\text {rd }}$ SAW): $43^{\text {rd }}$ SAW assessment summary report.. US Department of Commerce.; 2006. p. 46NEFSC Reference Document 06-14

Packer DB, Zetlin CA, Vitaliano JJ. Little skate, Leucoraja erinacea, life history and habitat characteristics. NOAA Technical Memorandum NMFS-NE-175. 2003a

Packer DB, Zetlin CA, Vitaliano JJ. Winter skate, Leucoraja ocellata, life history and habitat characteristics. NOAA Technical Memorandum NMFS-NE-179. 2003b

Payne EJ, Taylor DL. Effects of diet composition and trophic structure on mercury bioaccumulation in temperate flatfishes. Archives of Environmental Contamination and Toxicology. 2010; 58:431443. [PubMed: 19997909]

Peterson BJ, Howarth RW. Sulfur, carbon, and nitrogen isotopes used to trace organic-matter flow in the salt-marsh estuaries of Sapelo Island, Georgia. Limnology and Oceanography. 1987; 32:11951213.

Piraino MN, Taylor DL. Bioaccumulation and trophic transfer of mercury in striped bass (Morone saxatilis) and tautog (Tautoga onitis) from the Narragansett Bay (Rhode Island, USA). Marine Environmental Research. 2009; 67:117-128. [PubMed: 19150736]

Pruell RJ, Taplin BK, Lake JL, Jayaraman S. Nitrogen isotope ratios in estuarine biota collected along a nutrient gradient in Narragansett Bay, Rhode Island, USA. Marine Pollution Bulletin. 2006; 52:612-620. [PubMed: 16300802]

San Filippo, RA. MS thesis. San Jose State University; San Jose: 1995. Diet, gastric evacuation and estimates of daily ration of the gray smooth-hound, Mustelus californicus.; p. 71

Shiffman DS, Gallagher AJ, Boyle MD, Hammerschlag-Peyer CM, Hammerschlag N. Stable isotope analysis as a tool for elasmobranch conservation research: A primer for non-specialists. Marine and Freshwater Research. 2012; 62:635-643.

Smith BE, Link JS. The trophic dynamics of 50 finfish and 2 squid species on the northeast U.S. continental shelf. NOAA Technical Memorandum NMFS-NE-216. 2010

Smith GM, Weis JS. Predator-prey relationships in mummichogs (Fundulus heteroclitus (L.)): Effects of living in a polluted environment. Journal of Experimental Marine Biology and Ecology. 1997; 209:75-87.

Soldat VT. Age and size of spiny dogfish, Squalus acanthias, in the Northwest Atlantic. Northwest Atlantic Fisheries Organization Scientific Council Studies. 1982:47-52.

Stafford CR, Haines TA. Mercury contamination and growth rate in two piscivore populations. Environmental Toxicology and Chemistry. 2001; 20:2099-2101. [PubMed: 11521841]

Stehlik LL. Spiny dogfish, Squalus acanthias, life history and habitat characteristics. NOAA Technical Memorandum NMFS-NE-203. 2007

Storelli MM, Giacominelli-Stuffler R, Storelli A, D'Addabbo R, Palermo C, Marcotrigiano GO. Survey of total mercury and methylmercury levels in edible fish from the Adriatic Sea. Food Additives and Contaminants. 2003; 20:1114-1119. [PubMed: 14726274]

Storelli MM, Giacominelli-Stuffler R, Marcotrigiano GO. Total mercury in muscle of benthic and pelagic fish from the South Adriatic Sea (Italy). Food Additives and Contaminants. 1998; 15:876883. [PubMed: 10366996]

Suk SH, Smith SE, Ramon DA. Bioaccumulation of mercury in pelagic sharks from the northeast Pacific Ocean. CalCOFL Report. 2009; 50:172-180.

Sulikowski JA, Morin MD, Suk AH, Howell WH. Age and growth estimates of the winter skate (Leucoraja ocellata) in the western Gulf of Maine. Fishery Bulletin. 2003; 101:405-413.

Sunderland EM, Amirbahman A, Burgess N, Dalziel J, Harding G, Karagas M, Jones S, Shi X, Chen C. Mercury sources and fate in the Gulf of Maine. Environmental Research. 2012; 119:27-41. [PubMed: 22572623]

Szczebak JS, Taylor DL. Ontogenetic patterns in bluefish Pomatomus saltatrix feeding ecology and the effect on mercury biomagnification. Environmental Chemistry and Toxicology. 2011; 30:1447-1458. 
Trudel M, Rasmussen JB. Modeling the elimination of mercury by fish. Environmental Toxicology and Chemistry. 1997; 31:1716-1722.

US Environmental Protection Agency (US EPA). Mercury Study Report to Congress. Volumes I-VII: Fate and Transport of Mercury in the Environment, EPA-452/R-97-005. US Environmental Protection Agency; Washington, DC, USA.: 1997.

US Environmental Protection Agency (US EPA). Mercury in solids and solutions by thermal decomposition, amalgamation, and atomic absorption spectrophotometry. EPA Method 7473 Report. US Environmental Protection Agency; Washington, DC, USA.: 1998.

US Environmental Protection Agency (EPA). Fish tissue analysis for mercury and PCBs from a New York City commercial fish/seafood market. EPA/600/R-11/066F. US Environmental Protection Agency; Washington, DC, USA.: 2013.

Wang WX. Biodynamic understanding of mercury accumulation in marine and freshwater fish. Advances in Environmental Research. 2012; 1:15-35.

Wiener, JG.; Krabbenhoft, DP.; Heinz, GH.; Scheuhammer, AM. Ecotoxicology of mercury. In: Hoffman, DJ.; Rattner, BA.; Burton, GA., Jr.; Cairns, J., Jr., editors. Handbook of Ecotoxicology. Lewis Publishers; Boca Raton: 2003. p. 409-463.

Wiener, JG.; Spry, DJ. Toxicological significance of mercury in freshwater fish.. In: Beyer, WN.; Heinz, GH.; Redmon-Norwood, AW., editors. Environmental Contaminants in Wildlife: Interpreting Tissue Concentrations. Lewis Publishers; Boca Raton, Florida: 1996. p. 297-340.

Willett WC. Fish: Balancing health risks and benefits. American Journal of Preventive Medicine. 2005; 29:320-321. [PubMed: 16242596] 


\section{Research highlights}

- Mercury bioaccumulates in the cartilaginous fishes examined in this study.

Mercury content was higher in smooth dogfish, followed by spiny dogfish and skates.

- Trophic structure and diet preferences affect dogfish and skate mercury content.

Eating dogfish may adversely affect human health, whereas skates present low risk. 


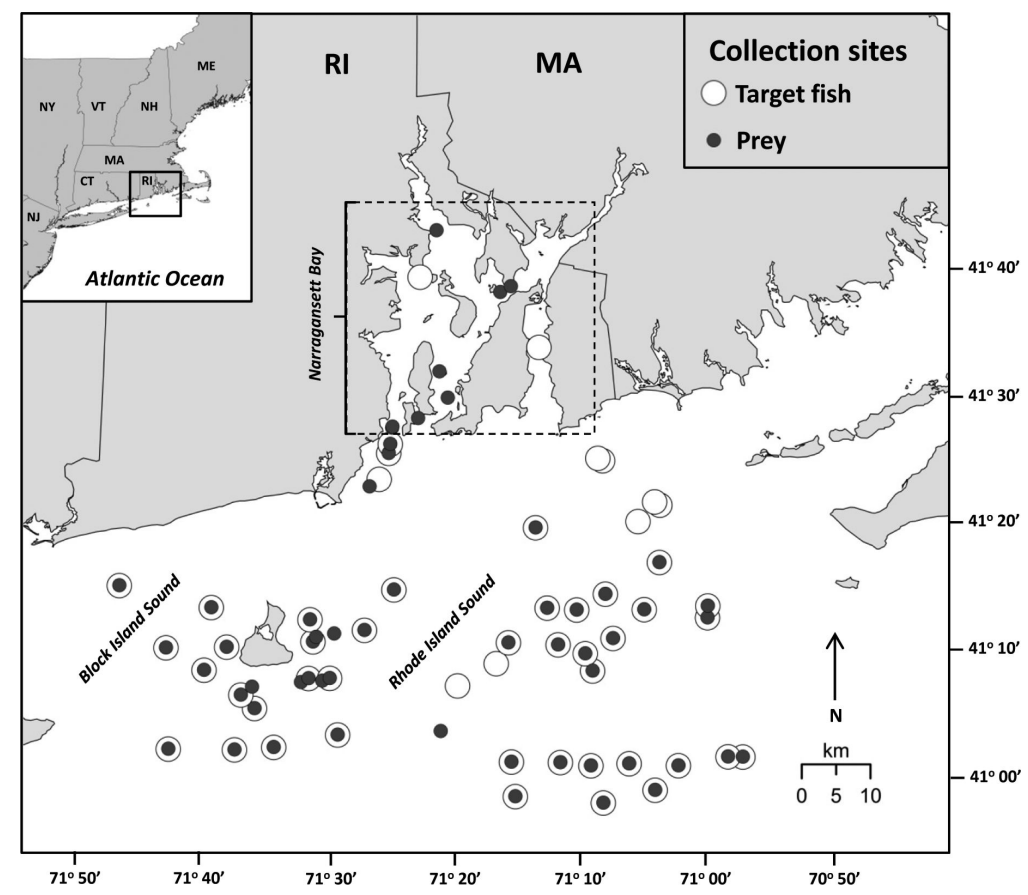

Fig 1.

Map of Rhode Island Sound, Block Island Sound, and Narragansett Bay (Rhode Island, USA) with points denoting collection sites of target fish (smooth dogfish, spiny dogfish, little skate, and winter skate) and prey (scup, butterfish, longfin squid, and cancer crabs). 

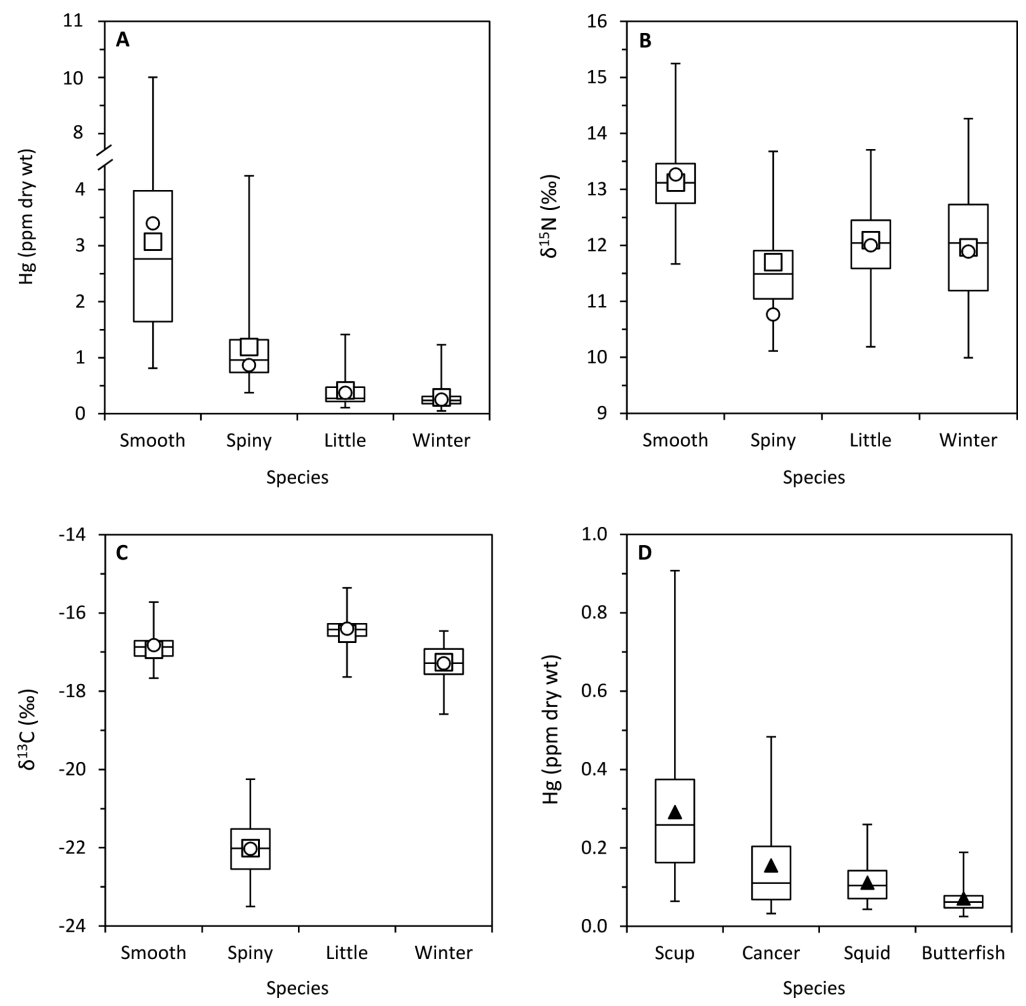

Fig. 2.

Total mercury (Hg) concentrations (ppm dry weight) of target fish (A) and prey (D), and stable nitrogen $(B)$ and carbon $(C)$ isotope signatures $\left(\delta^{15} \mathrm{~N}\right.$ and $\delta^{13} \mathrm{C} ; \%$ ) of target fish. Box plots illustrate the median, $1^{\text {st }}$ and $3^{\text {rd }}$ quartiles, and maximum and minimum values. Open squares and circles represent means for female and male target fish, respectively, and solid triangles represent means for prey. Target fish include smooth dogfish, spiny dogfish, little skate, and winter skate, and prey include scup, cancer crabs, longfin squid, and butterfish. 

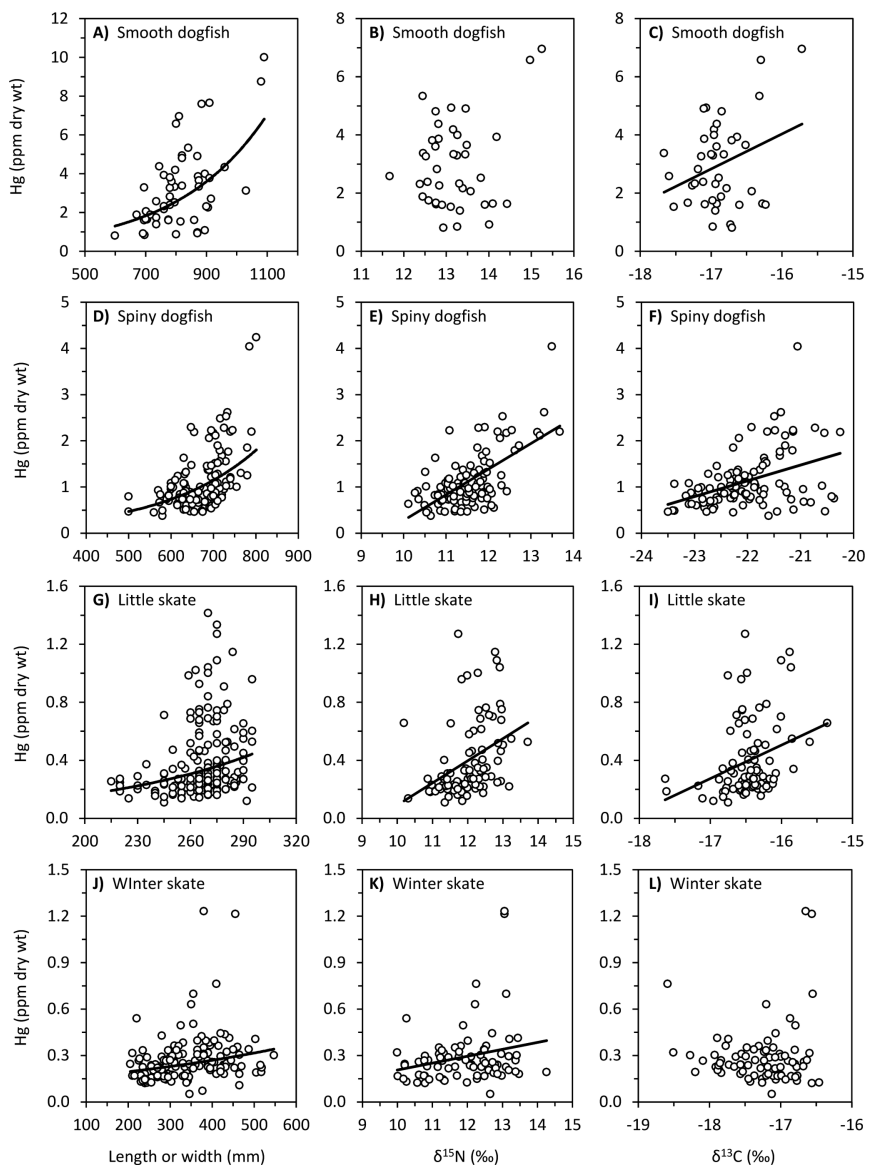

Fig. 3.

Total mercury ( $\mathrm{Hg}$ ) concentrations (ppm dry weight) of target fish as a function of body size (total length or disk width; $\mathrm{mm}$ ), and stable nitrogen and carbon isotope signatures $\left(\delta^{15} \mathrm{~N}\right.$ and $\delta^{13} \mathrm{C} ; \%$ ). Target fish include smooth dogfish (A-C), spiny dogfish (D-F), little skates (G-I), and winter skates (J-L). For significant relationships, exponential and linear regression models were fit to size and isotope data, respectively. 

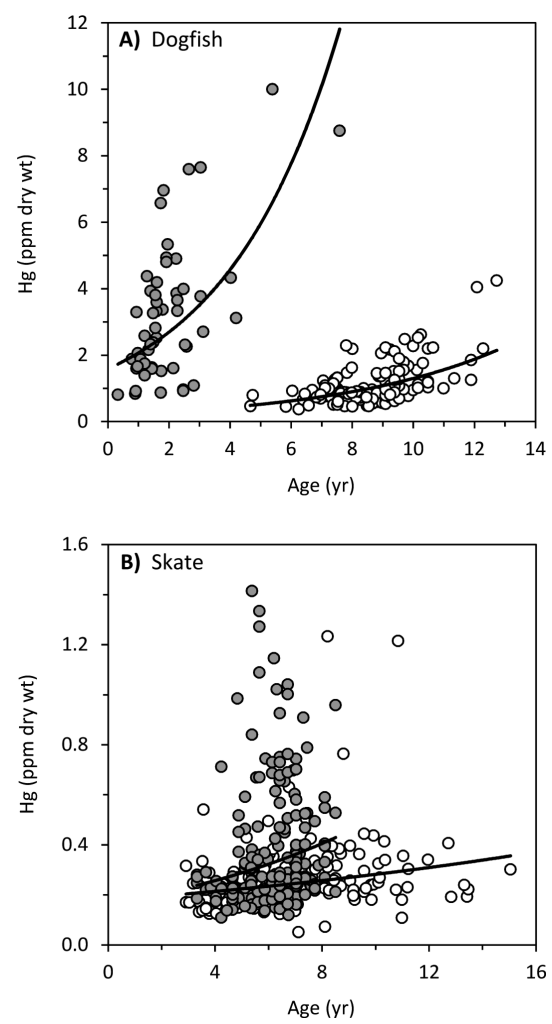

Fig. 4.

Total mercury ( $\mathrm{Hg}$ ) concentrations (ppm dry weight) of dogfish (A) and skates (B) as a function of age. Smooth dogfish and little skates are denoted by solid circles, whereas spiny dogfish and winter skates are represented by open circles. Exponential regression models were fit to species-specific data. 

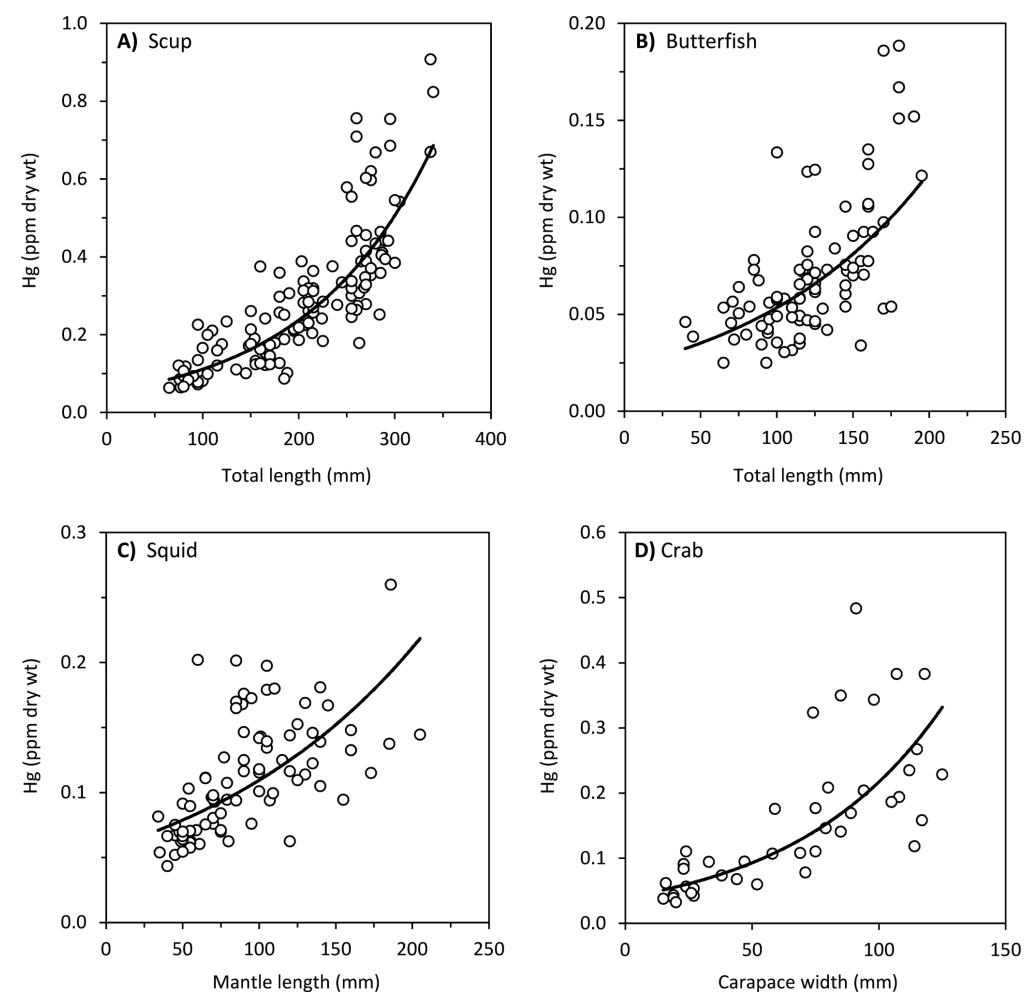

Fig. 5.

Total mercury (Hg) concentrations (ppm dry weight) of scup (A), butterfish (B), longfin squid (C), and cancer crabs (D) as a function of body size (total length, mantle length, or carapace width; mm). Exponential regression models were fit to the data. 


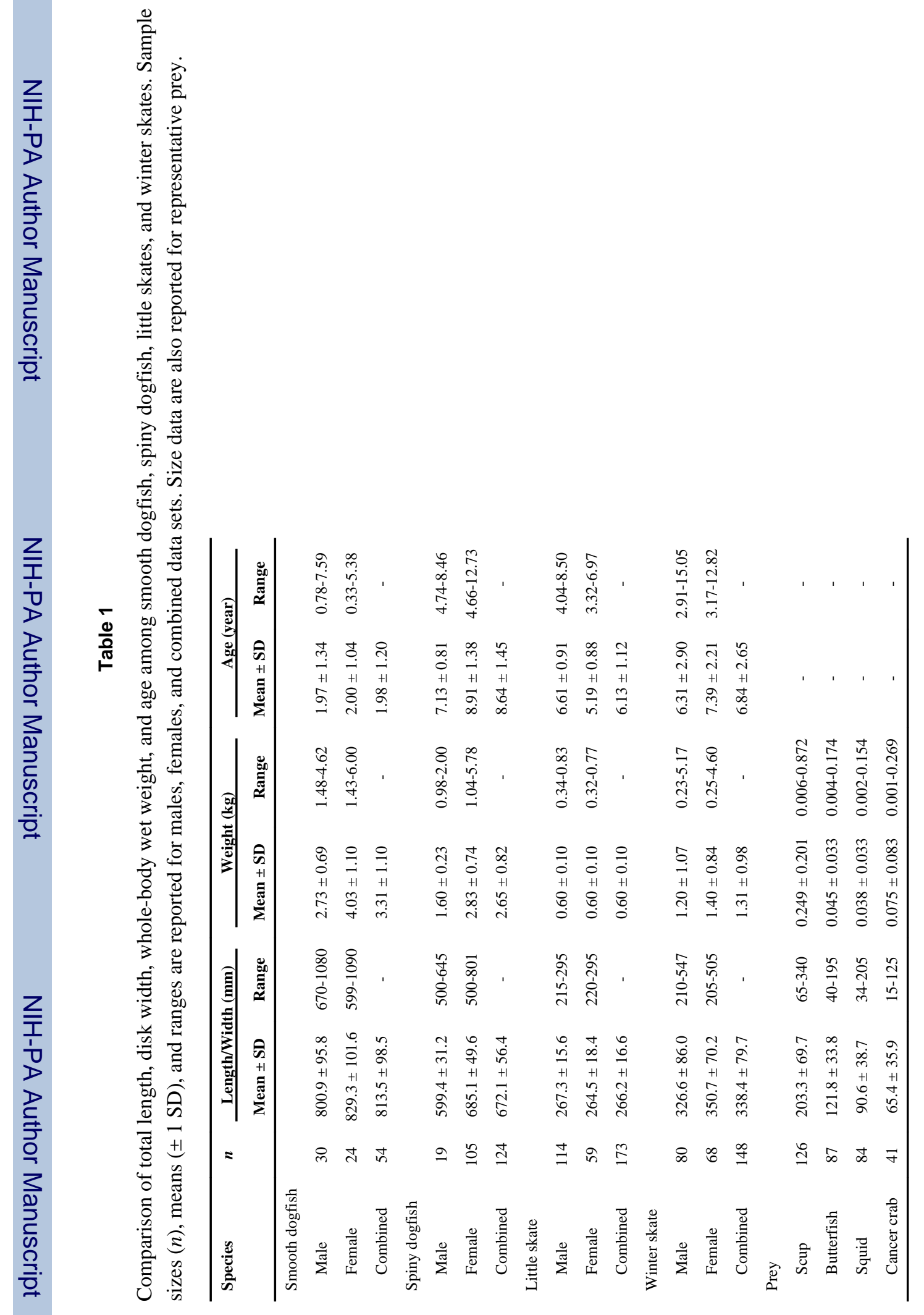




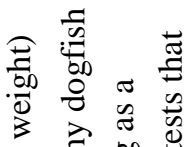

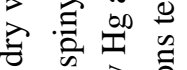

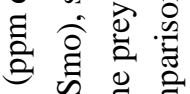

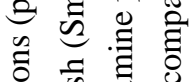

䒕 营

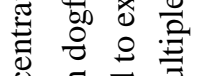

苛

OD है छ

ए

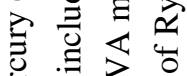

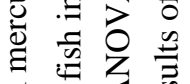

ส

잉

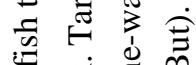

$\dot{x} \dot{0}$

$\Phi_{\infty} \infty_{\infty}^{\infty} \approx \pi$

ప

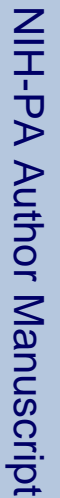

茟.

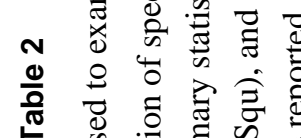

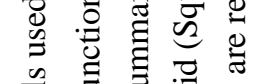

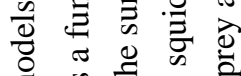

$\stackrel{3}{g}=$

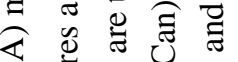

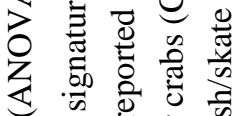

过

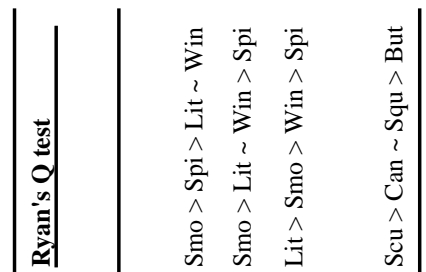

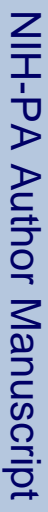

र

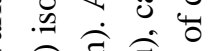

ิิ)

$\therefore$ ए $\sum_{0}^{0}$

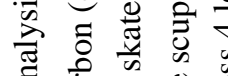

ส

ते

3 ज

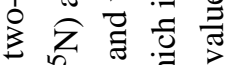

ᄒํ.

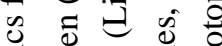

苞苞苟

का व 0 की

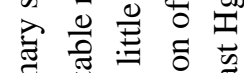

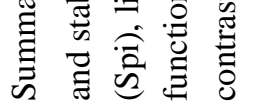

a 2 âे

:

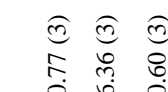

$1=$ 둥

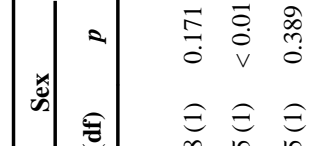

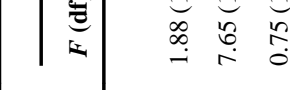

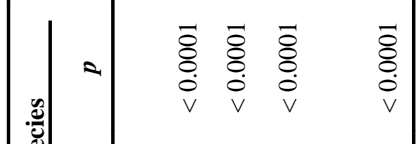

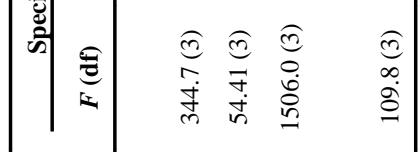

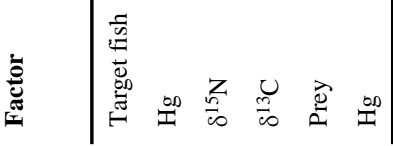

Mar Environ Res. Author manuscript; available in PMC 2015 August 01. 


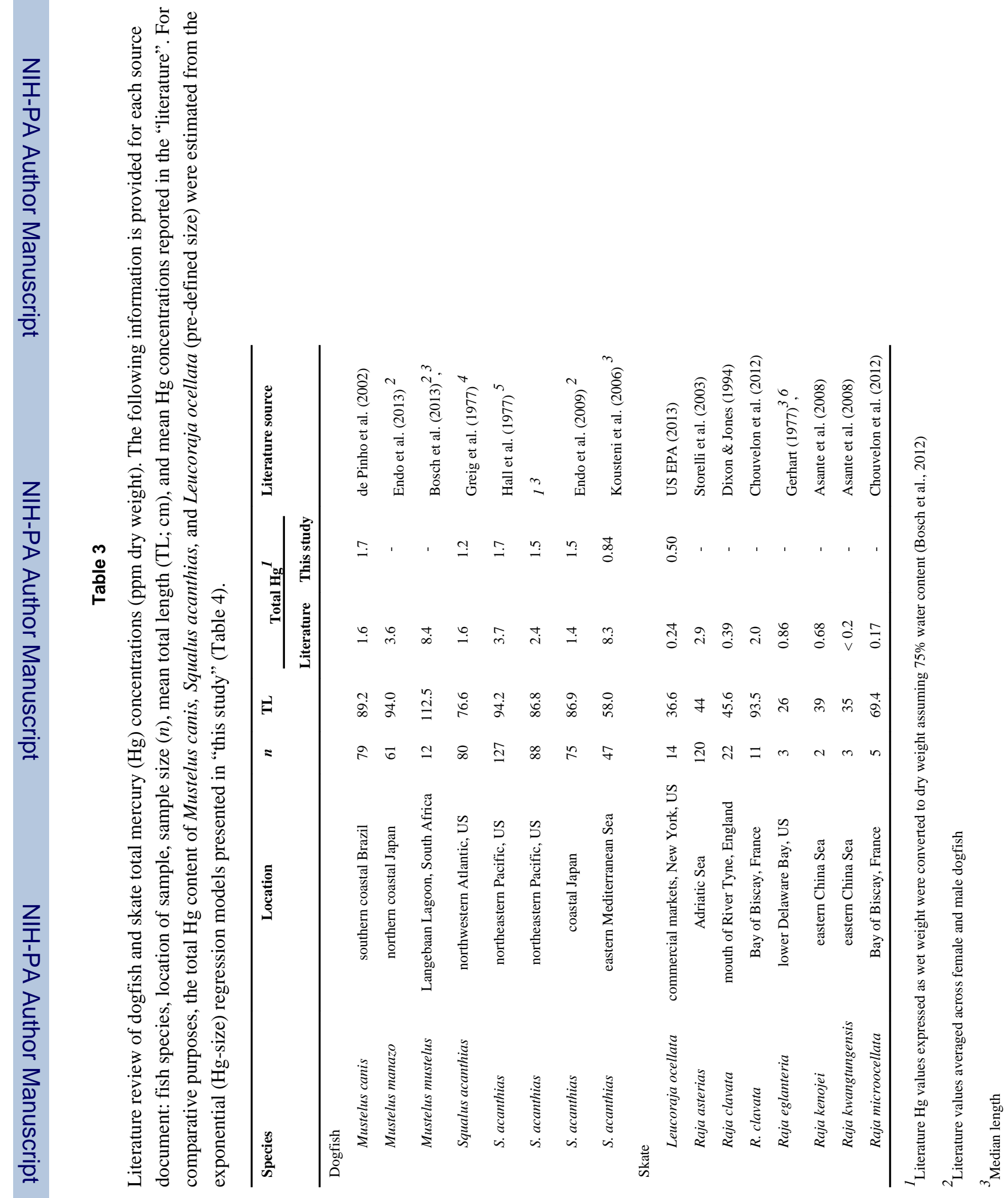




\section{Table 4}

Summary statistics for univariate (non-linear) exponential and linear regression models used to examine the effect of body size [mm; total length (TL), disk width (DW), mantle length (ML), and carapace width (CW)], age (years), and stable nitrogen $\left(\delta^{15} \mathrm{~N}\right)$ and carbon $\left(\delta^{13} \mathrm{C}\right)$ isotope signatures on biota total mercury $(\mathrm{Hg})$ concentrations (ppm dry weight).

\begin{tabular}{|c|c|c|c|c|}
\hline Species/Relationship & Regression model & $F(d f)$ & $p$ & $R^{2}$ \\
\hline \multicolumn{5}{|l|}{ Smooth dogfish } \\
\hline $\mathrm{Hg}-\mathrm{TL}$ & $\log (H g)=1.47 \mathrm{E}^{-3} \times T L-0.763$ & $19.56(1,53)$ & $<0.0001$ & 0.273 \\
\hline $\mathrm{Hg}-\mathrm{Age}$ & $\log (H g)=0.115 \times A g e+0.200$ & $17.74(1,53)$ & $<0.0001$ & 0.252 \\
\hline $\mathrm{Hg}-\delta^{15} \mathrm{~N}$ & $H g=0.516 \times \delta^{15} N-3.841$ & $2.53(1,40)$ & 0.120 & 0.061 \\
\hline $\mathrm{Hg}-\delta^{13} \mathrm{C}$ & $H g=1.205 \times \delta^{13} C+23.32$ & $4.10(1,40)$ & $<0.05$ & 0.095 \\
\hline \multicolumn{5}{|l|}{ Spiny dogfish } \\
\hline $\mathrm{Hg}-\mathrm{TL}$ & $\log (H g)=1.99 \mathrm{E}^{-3} \times T L-1.332$ & $49.14(1,123)$ & $<0.0001$ & 0.287 \\
\hline Hg-Age & $\log (H g)=0.081 \times A g e-0.696$ & $56.70(1,123)$ & $<0.0001$ & 0.317 \\
\hline $\mathrm{Hg}-\delta^{15} \mathrm{~N}$ & $H g=0.555 \times \delta^{15} N-5.276$ & $72.16(1,105)$ & $<0.0001$ & 0.410 \\
\hline $\mathrm{Hg}-\delta^{13} \mathrm{C}$ & $H g=0.342 \times \delta^{13} C+8.654$ & $21.82(1,105)$ & $<0.0001$ & 0.173 \\
\hline \multicolumn{5}{|l|}{ Little skate } \\
\hline $\mathrm{Hg}-\mathrm{DW}$ & $\log (H g)=4.56 \mathrm{E}^{3} \times D W-1.698$ & $18.51(1,172)$ & $<0.0001$ & 0.098 \\
\hline $\mathrm{Hg}-\mathrm{Age}$ & $\log (H g)=0.050 \times A g e-0.792$ & $9.66(1,172)$ & $<0.005$ & 0.054 \\
\hline $\mathrm{Hg}-\delta^{15} \mathrm{~N}$ & $H g=0.153 \times \delta^{15} N-1.439$ & $15.01(1,87)$ & $<0.0005$ & 0.149 \\
\hline $\mathrm{Hg}-\delta^{13} \mathrm{C}$ & $H g=0.231 \times \delta^{13} C+4.203$ & $8.93(1,87)$ & $<0.005$ & 0.094 \\
\hline \multicolumn{5}{|l|}{ Winter skate } \\
\hline $\mathrm{Hg}-\mathrm{DW}$ & $\log (H g)=6.93 \mathrm{E}^{-4} \times D W-0.849$ & $13.24(1,147)$ & $<0.0005$ & 0.083 \\
\hline Hg-Age & $\log (H g)=0.020 \times A g e-0.750$ & $11.95(1,147)$ & $<0.001$ & 0.076 \\
\hline $\mathrm{Hg}-\delta^{15} \mathrm{~N}$ & $H g=0.044 \times \delta^{15} N-0.238$ & $4.41(1,79)$ & $<0.05$ & 0.054 \\
\hline $\mathrm{Hg}-\delta^{13} \mathrm{C}$ & $H g=3.48 \mathrm{E}^{-2} \times \delta^{13} C+0.893$ & $0.58(1,79)$ & 0.450 & 0.007 \\
\hline \multicolumn{5}{|l|}{ Scup } \\
\hline $\mathrm{Hg}-\mathrm{TL}$ & $\log (H g)=3.29 \mathrm{E}^{-3} \times T L-1.283$ & $338.6(1,125)$ & $<0.0001$ & 0.732 \\
\hline \multicolumn{5}{|l|}{ Butterfish } \\
\hline $\mathrm{Hg}-\mathrm{TL}$ & $\log (H g)=3.63 \mathrm{E}^{-3} \times T L-1.636$ & $58.38(1,86)$ & $<0.0001$ & 0.407 \\
\hline \multicolumn{5}{|l|}{ Squid } \\
\hline $\mathrm{Hg}-\mathrm{ML}$ & $\log (H g)=2.86 \mathrm{E}^{-3} \times M L-1.246$ & $57.18(1,83)$ & $<0.0001$ & 0.411 \\
\hline \multicolumn{5}{|l|}{ Cancer crab } \\
\hline $\mathrm{Hg}-\mathrm{CW}$ & $\log (H g)=7.36 \mathrm{E}^{-3} \times C W-1.399$ & $86.35(1,40)$ & $<0.0001$ & 0.689 \\
\hline
\end{tabular}




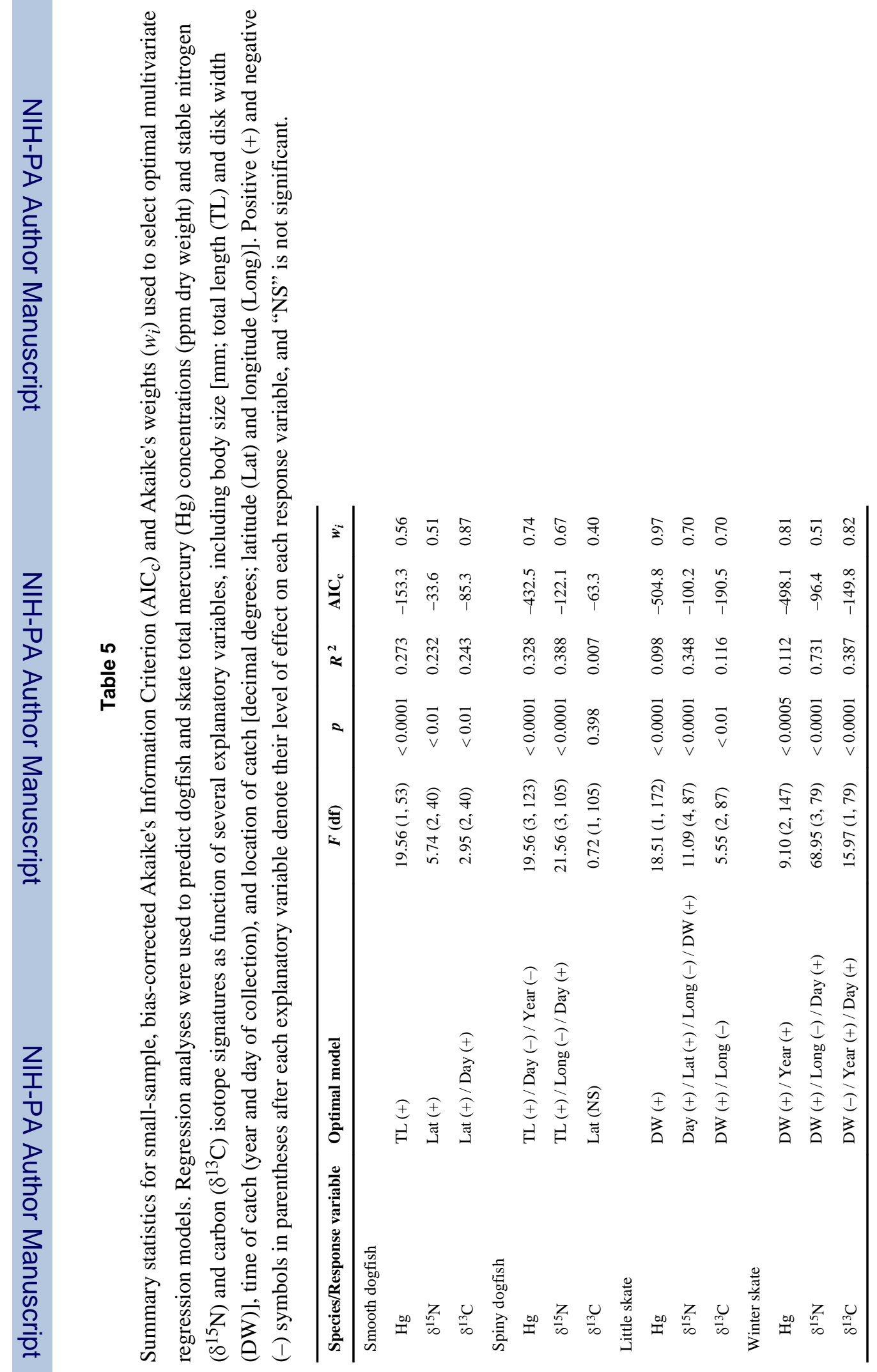


Table 6

Summary statistics for analysis of covariance (ANCOVA) models used to examine the effect of sex and species on intra- and inter-specific total mercury bioaccumulation rates (ppm dry weight as function of age).

\begin{tabular}{|c|c|c|c|c|c|c|c|c|c|c|}
\hline \multirow{2}{*}{\multicolumn{2}{|c|}{ Factor }} & \multicolumn{3}{|c|}{ Age $\times$ Sex } & \multicolumn{4}{|c|}{ Age } & \multicolumn{2}{|c|}{ Sex } \\
\hline & & \multicolumn{2}{|c|}{$F($ df $)$} & $p$ & \multicolumn{2}{|c|}{$F(d f)$} & \multicolumn{2}{|c|}{$p$} & $F(d f)$ & $p$ \\
\hline \multicolumn{2}{|c|}{ Smooth dogfish } & \multicolumn{2}{|c|}{$1.63(1)$} & 0.208 & \multicolumn{2}{|c|}{$17.25(1)$} & \multicolumn{2}{|c|}{$<0.0001$} & $0.08(1)$ & 0.778 \\
\hline \multicolumn{2}{|c|}{ Spiny dogfish } & \multicolumn{2}{|c|}{$1.17(1)$} & 0.282 & \multicolumn{2}{|c|}{$53.44(1)$} & \multicolumn{2}{|c|}{$<0.0001$} & $1.65(1)$ & 0.202 \\
\hline \multicolumn{2}{|l|}{ Little skate } & \multicolumn{2}{|c|}{$0.38(1)$} & 0.539 & \multicolumn{2}{|c|}{$17.75(1)$} & \multicolumn{2}{|c|}{$<0.0001$} & $7.82(1)$ & $<0.01$ \\
\hline \multicolumn{2}{|c|}{ Winter skate } & \multicolumn{2}{|c|}{$0.59(1)$} & 0.443 & \multicolumn{2}{|c|}{$10.43(1)$} & \multicolumn{2}{|c|}{$<0.005$} & $0.52(1)$ & 0.473 \\
\hline \multirow[t]{2}{*}{ Factor } & \multicolumn{3}{|c|}{ Age $\times$ Species } & \multicolumn{4}{|c|}{ Age } & \multicolumn{3}{|c|}{ Species } \\
\hline & \multicolumn{2}{|c|}{$F(\mathbf{d f})$} & $p$ & \multicolumn{2}{|c|}{$F(d f)$} & \multicolumn{2}{|c|}{$p$} & \multicolumn{2}{|c|}{$F(d f)$} & $p$ \\
\hline Dogfishes & \multicolumn{2}{|c|}{$2.01(1)$} & 0.158 & \multicolumn{2}{|c|}{$67.68(1)$} & \multicolumn{2}{|c|}{$<0.0001$} & 168 & $.02(1)$ & $<0.0001$ \\
\hline Skates & 3.5 & & 0.061 & 17. & 9 (1) & $<0$ & 0001 & & $55(1)$ & $<0.0001$ \\
\hline
\end{tabular}




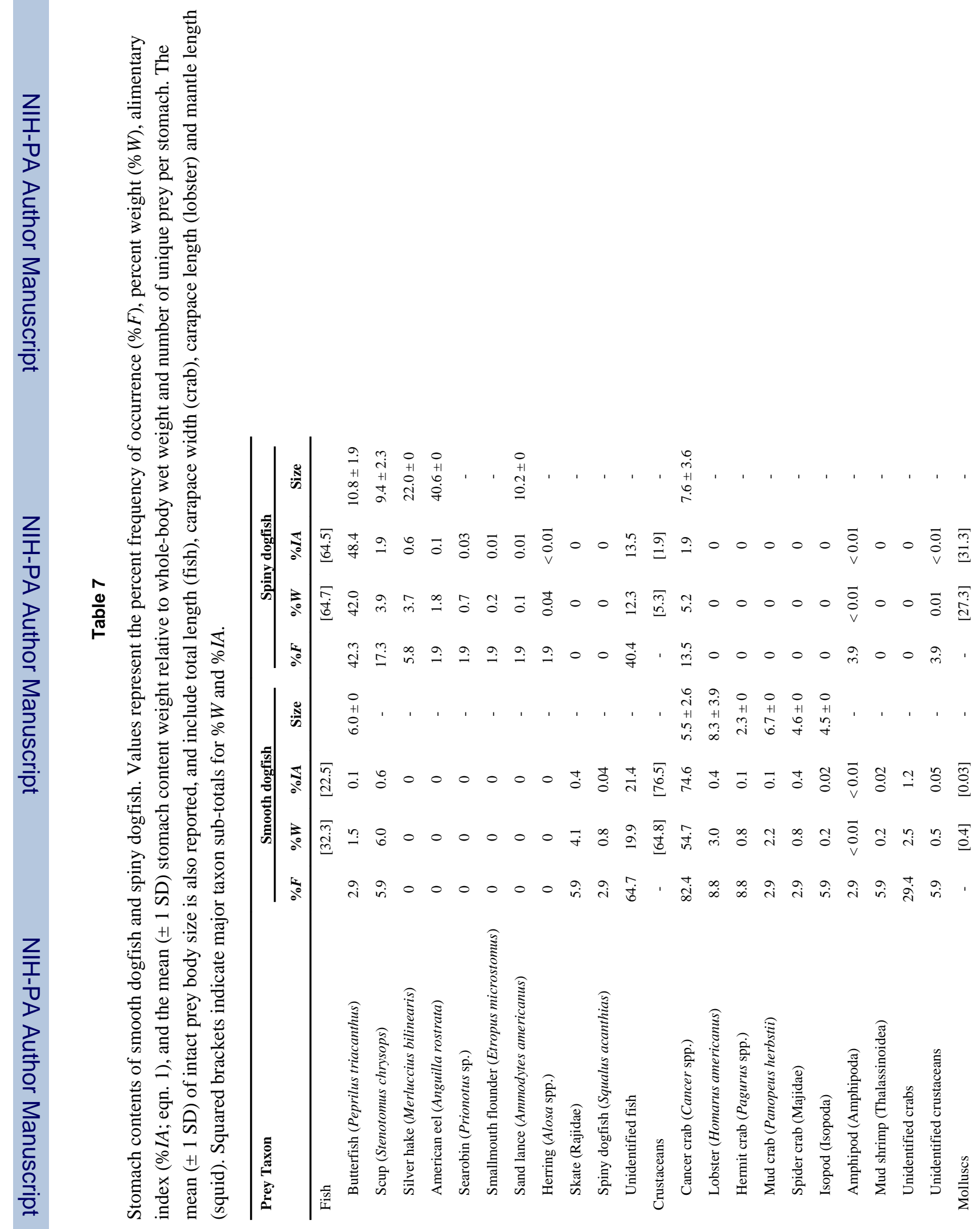




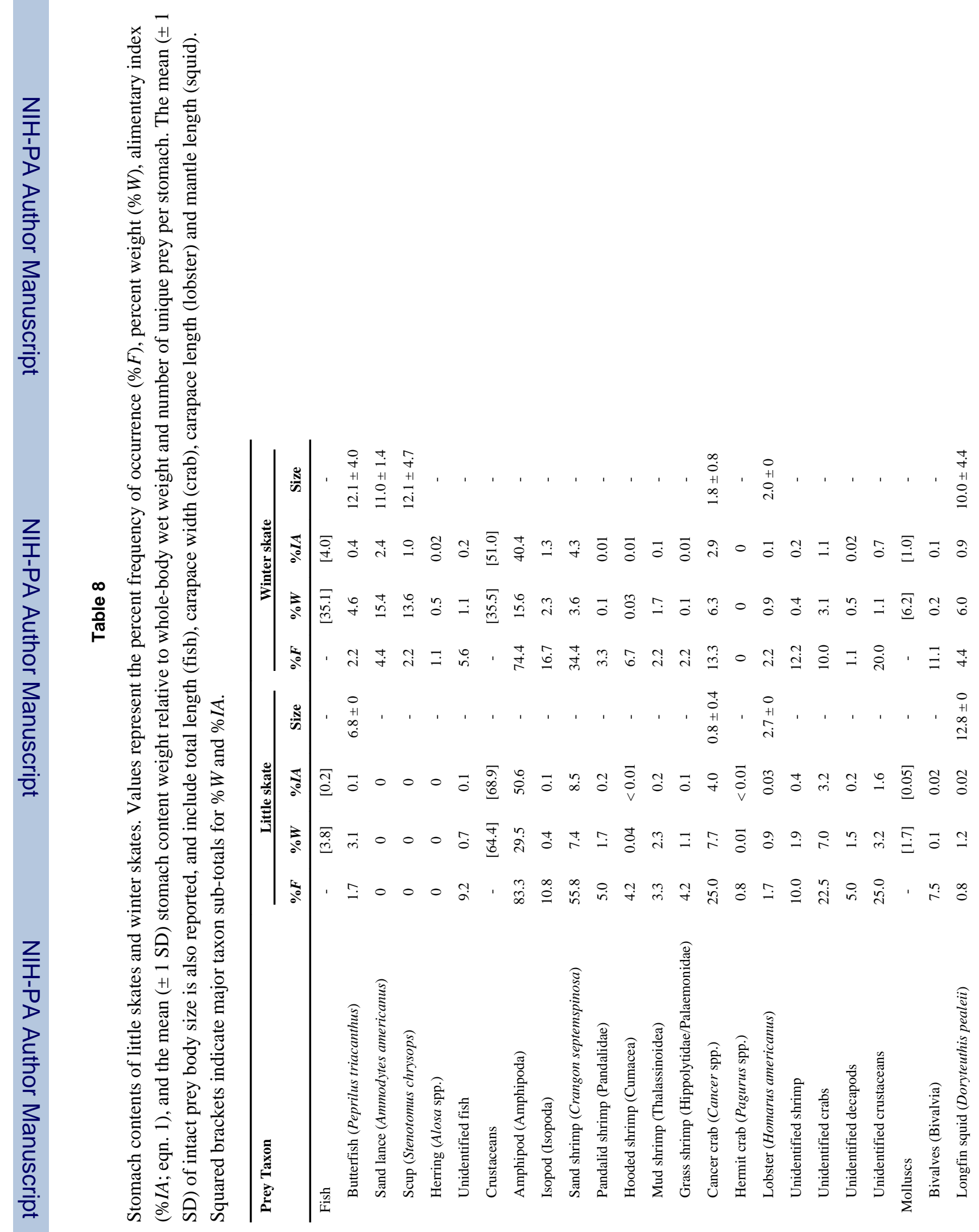


